\title{
متطلبات تأثير استخدام الفصول الذكية على التعليم
}

! إبنهال الفوزاه

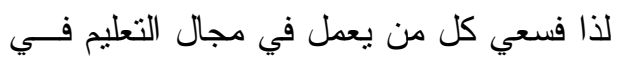

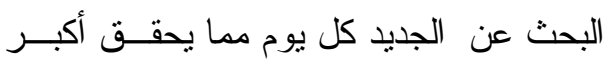

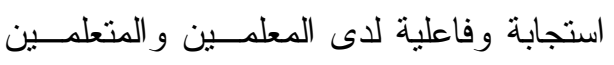

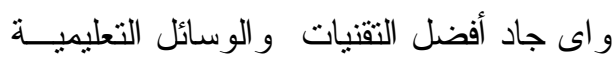
ومو اكبة سرعة العصر وتطوره؛ لذا وجـــنا

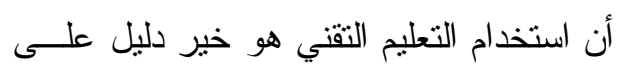
ذلك وهو المستقبل الذي سوف يسود العـالم و الذي قد بدأ بالفعل في بعض الدول المنقدمة علمية.

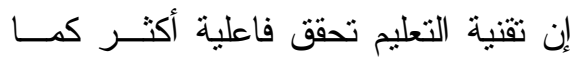

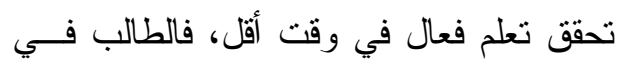

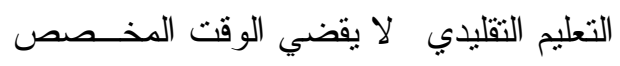

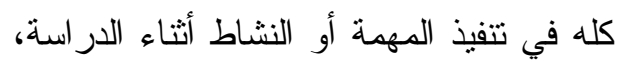

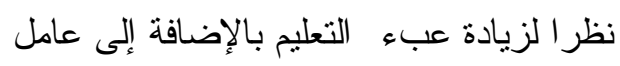

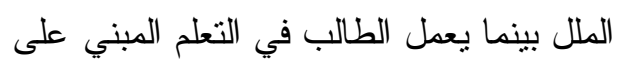

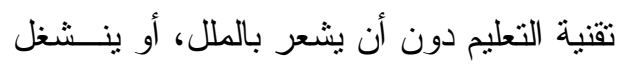
عن المهمة أو النشاط.

كما إن التعليم عن طريق اللغة اللفظيــة

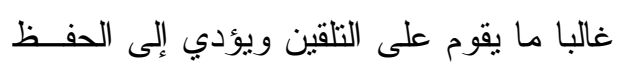
دون إتاحة الفرصة للكثف و التجريب و الفهم

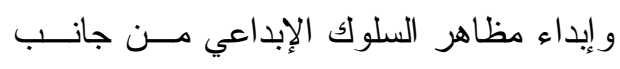

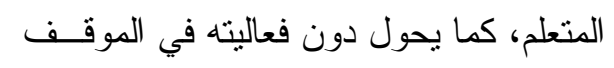

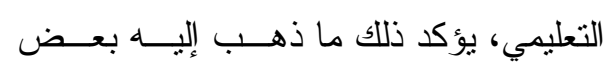

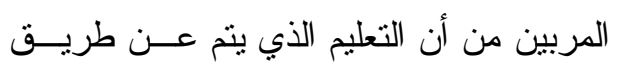

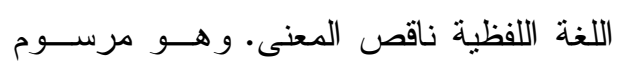

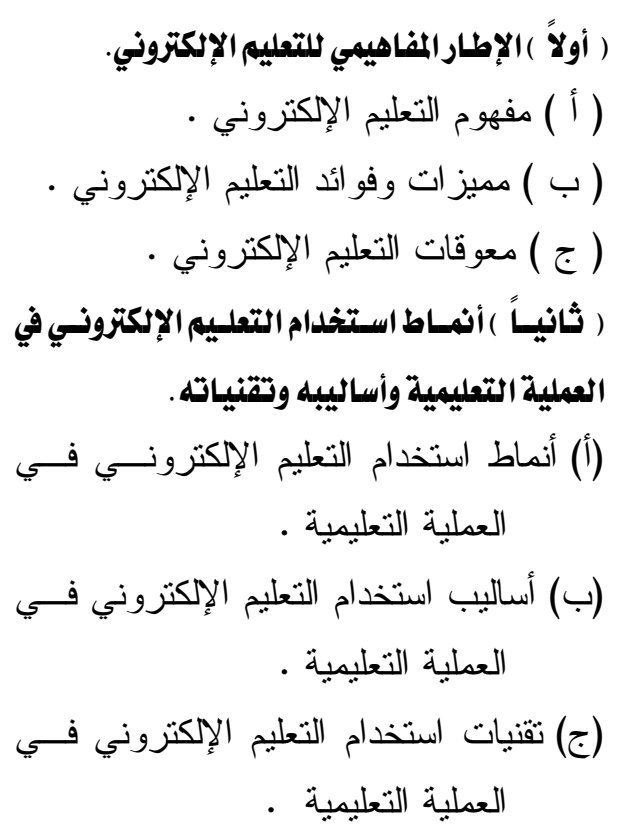
( أولاً ) الإطار المفاهيمي للتعليه الإلكتروني. 
بطابع الحفظ والاستظهار وليس من شــــ أن الروتين الذي اعناده الطلبــة فـــي الفـصول

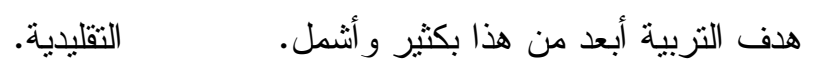

وفي الوقت الر اهن نرى أن الكثيــر مــن

مشكلة البحث

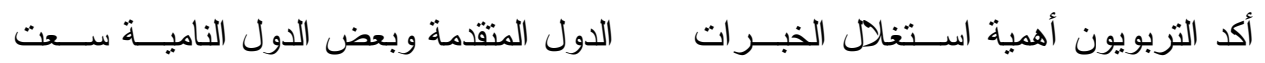

الحسية في المو اقف التعليميــة وعلــى دور إلى نطبيق نظام الفصول الذكية ســـواء كــان

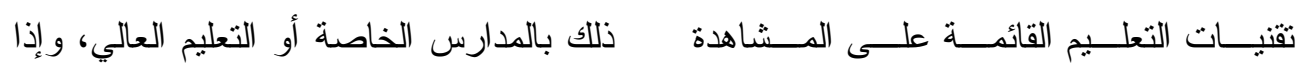

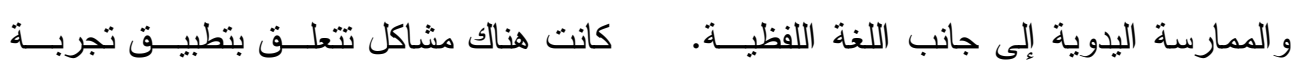

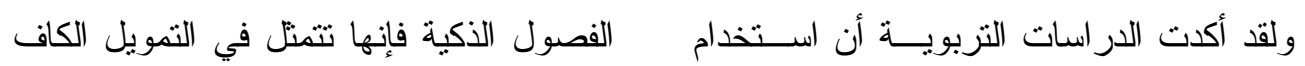

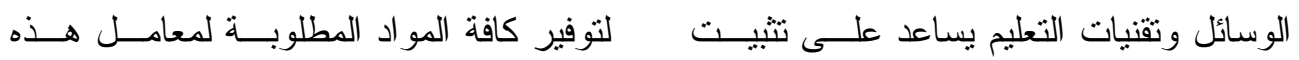

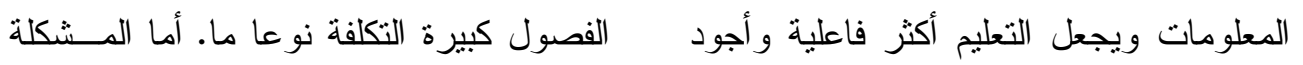

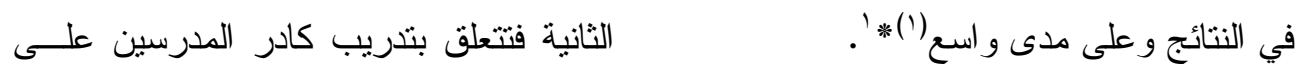

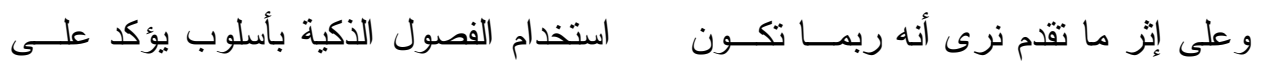

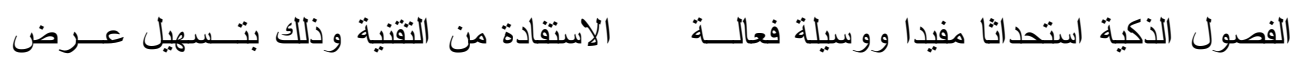

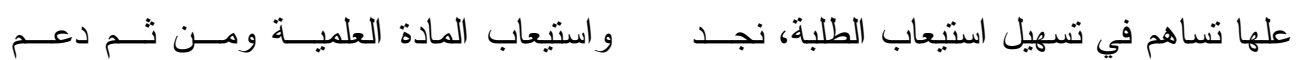

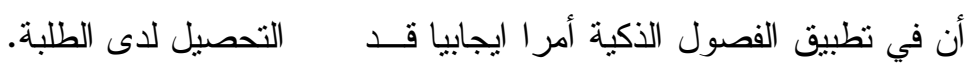

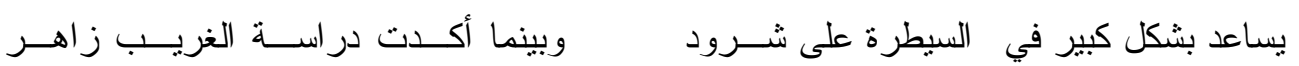

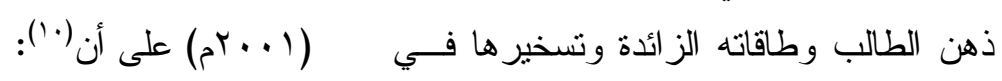

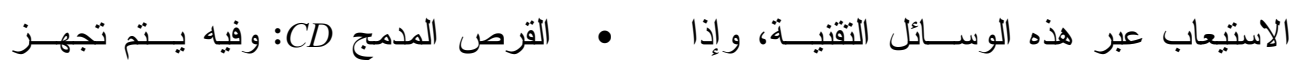

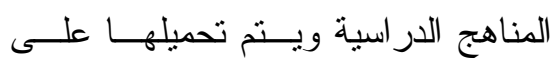

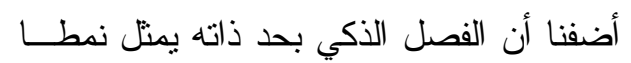

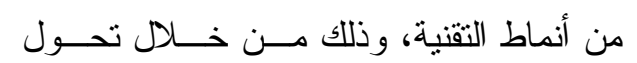

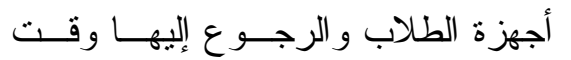

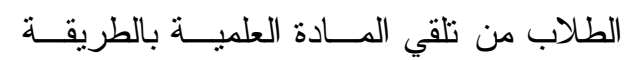

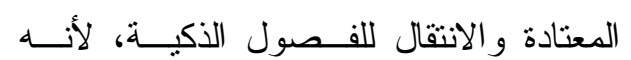
وبغض النظر عن تسهيل الفـصول الذكيــة

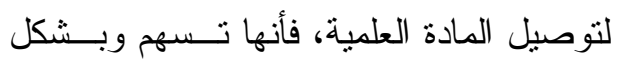

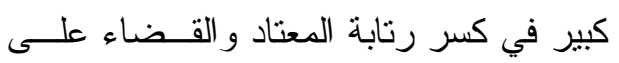

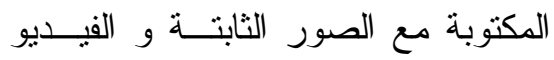
(صور متحركة). كما توفر هذه التقنيــة 
و الخبرات وعناصر المعلومات في جــو

تفاعلي يهدف إلى تحقيق التعاون و التفاهم

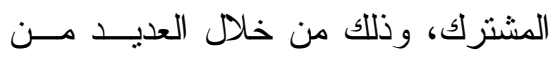

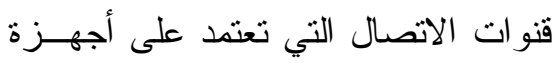

الحاسب وكاميرات الفيديو الرقمية.

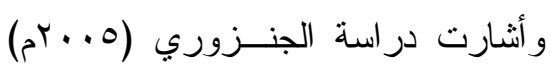

إلى أن (")

الفيديو التفاعلي Interactive: هو نظام بني على أساس الخصائص التفاعلية للحاسب الآلي، يربط بين نظام الحاسـب الآلــي

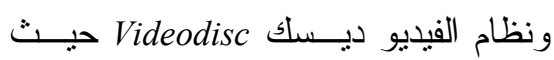

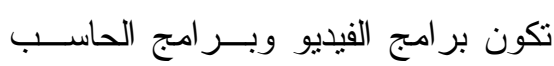

تحت تحكم المتعلم، ويمكن تشغيله بقلــ

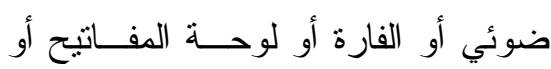

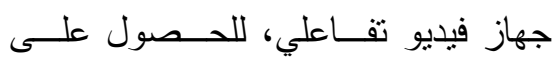
مصادر متعددة للتعلم، في وقت قليل. وتوصلت معظم دراسات المؤتمر العلمي

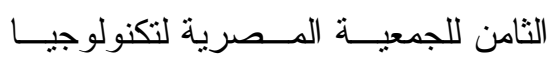

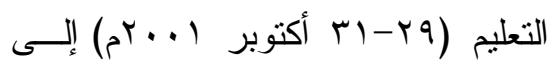
أن (17) - (17)

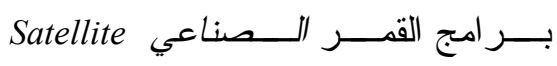
في هذه التقنية نوظف بر امج الأقمار الصناعية المنصلة بنظام الحاسب و المتصلة بخط مباثر مع شبكة اتصالات

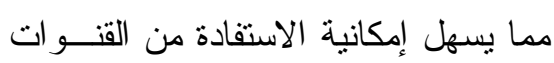

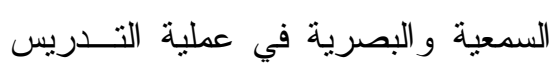
و التعليم، ويجعلها أكثر تفاعلا وحيويــة.
للمعلمين و المتعلمين أبعادا إضافية لأثـر

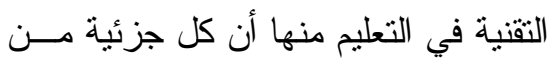

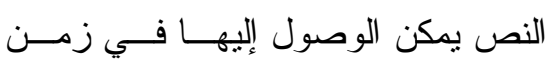
قصير لا يتعدى التثواني.

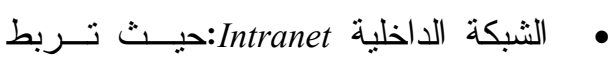

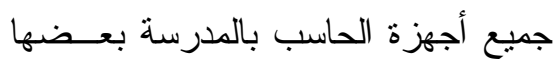

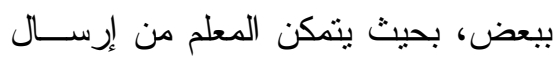

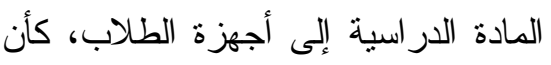

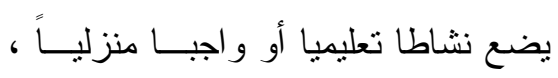
ويطلب من جميع الطلاب تتفيذه وإرساله مرة أخرى إلى جهازه.

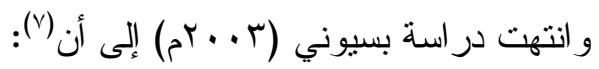

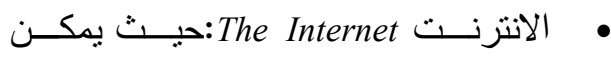
توظيفها كوسيط إعلامي وتعليمي في آن واحد، فيمكن لمؤسسة تعليمية ما أن تعلن

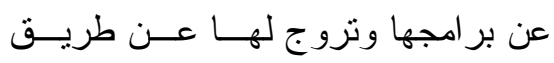

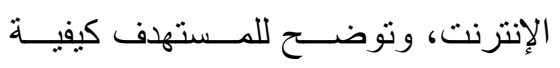

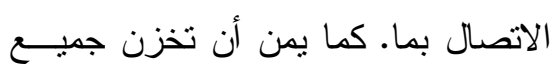
بر بحياتها التعليمية على الموقع الخاص لمن لتحن

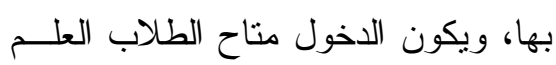
و المعرفة حسب الطريقة التـي نتبعهــا المؤسسة.

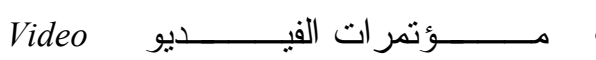
هي عبارة عـن اتــصـال

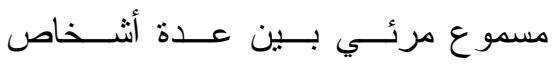
يتو اجدون في أماكن جغر افيــة مختلفـــة منباعدة، يم فيها مناقتشة وتبادل الأفكـار 
وفي هذه التقنية يتوحد محتــوى التعلــيم لـلذا أمكن تحلديـل مشكلة البحث الـراهن في التساؤل

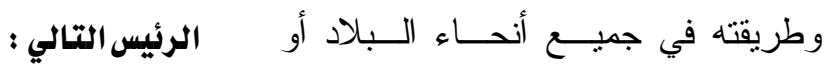

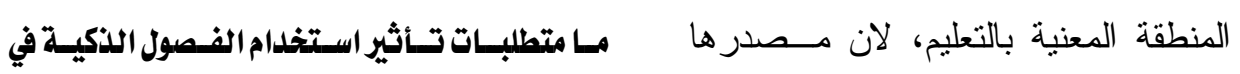

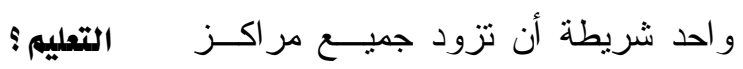

ويتفرع من هذا التساؤل الرئيس التساؤلات الفرعية الاستقبال بأجهزة استقبال و بت خاصـــة تردة

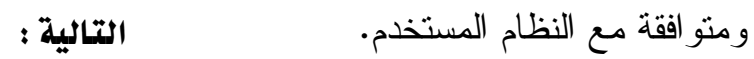
ا ـ الت ماليه" الإطار المفاهيمي للتعليم الإلكتروني

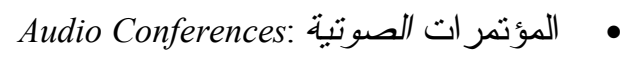
، وما معوقات تتفيذه ؟ تعد تقنية المؤتمرات الصوتية المسموعة

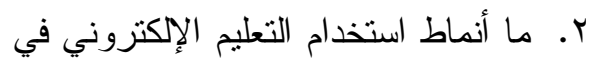
أقل تكلفة مقارنـــة بمــؤتمر ات الفبـديو العملية التعليمية ؟ وأيسر نظاما ومرونة وقابلية للتطبيق في r. ما طبيعة الفصول الذكية ؟ وما مر احل بل

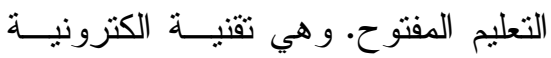
التخطيط لها ؟ ع. ـ ما متطلبات تفعيل التكنولوجيا المكونـــة

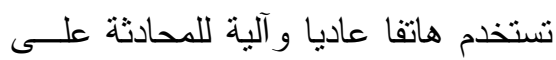
هيئة خطوط هاتقية توصـل المتحـدث للفصول الذكية في التعليم ؟ (المعلم ) بعدد من المستقلين ( الطلاب ) أهداف البحث

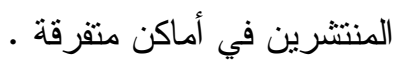
يستهدف البحث الر اهن تحديد متطلبــات

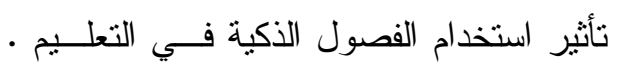
هي - الفصول الافتراضية : فصول شبيهة بالفصول التقليدية من حيث وذلك من خلا الإجابة البحثية عن التساؤلات

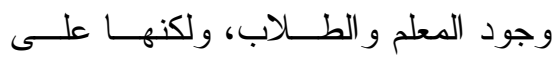
الفرعية للمشكلة البحثية للبحث الر اهن .

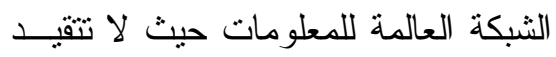
أهمية البحث

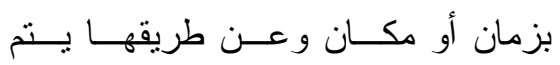
يتوقع أن يُسهم البحث الر اهن في تعميـق استحداث بيئات تعليمية افتر اضية بحيث مرن المهام التالية للقائمين علي تطوير التعليم تقنياً يسنطيع الطلبة التجمع بو اسطة الـشبكات

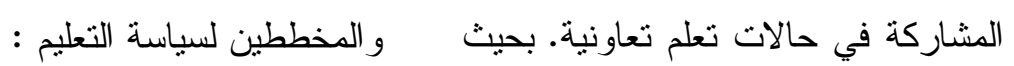
التعريف بالإطـــار المفــاهيمي للتعلـــيم

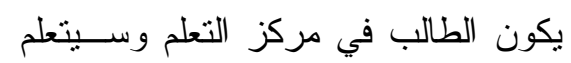
الإلكتروني ومعوقات تتفيذه علـي أرض لإصن من اجل الفهم و الاستيعاب المبارك.

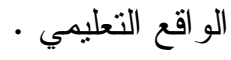




$$
\begin{aligned}
& \text { • الوقوف علي أبرز أنماط استخدام التعليم وغيرها وعروض البوربوينت و التــي مـن }
\end{aligned}
$$

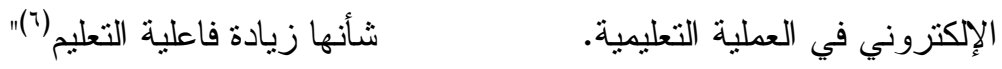

$$
\begin{aligned}
& \text { أولا ا الإطار المفاهيمي للتعليم الإلكتروني. }
\end{aligned}
$$

\section{مصطلحات البحث}

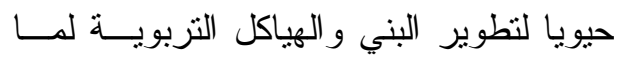
تقدمة التكنولوجيا من نقلة نوعية فــي إعـادة

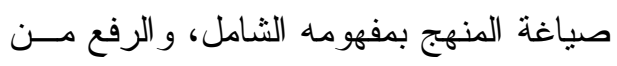

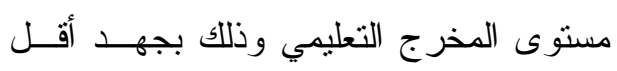

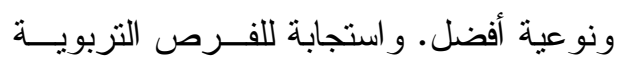

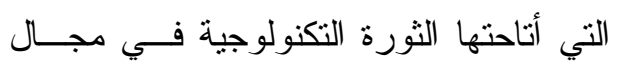

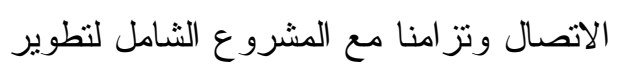
التعليم على كافة المستويات ظهر مــصطلح التعليم الإلكتروني وذللك لإيجاد التز ابط بــين مستجدات الفكر التربوي وتوظيف التكنولوجيا

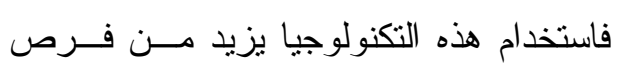

الفصول الذكية "هي بيئة تعلم تفاعلية يتو اجد

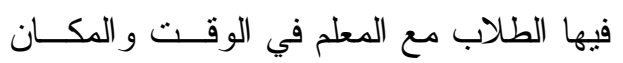

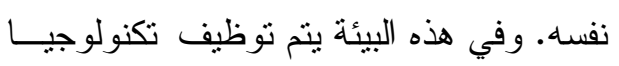

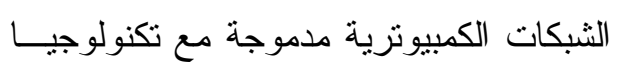

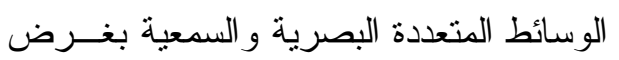
حدوث عملية التعلم و إثر اءها بأقصى فاعليــــة ممكنة (^)".

وتعرف إجرائيا: بأنها فصول مجهزة بوسائل

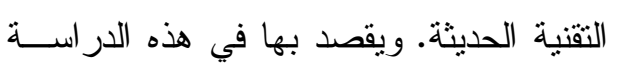

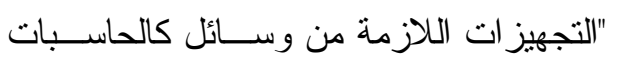

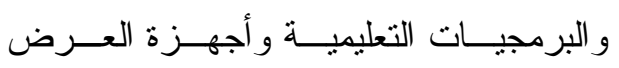


يفضله دون الالتز ام بالحضور إلــى قاعــات الدر اسة في أوقات محددة (ro)

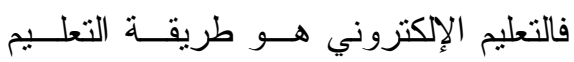

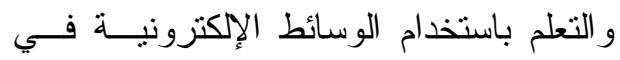

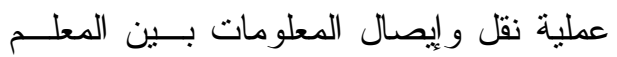
و المتعلم منل الحو اسيب و الثبكات، و الوسائط

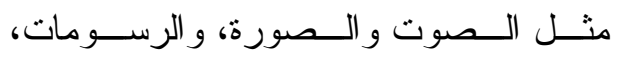
و المكتبات الإككترونية، و الإنترنت، و غير ها.

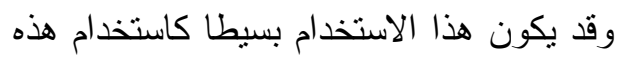

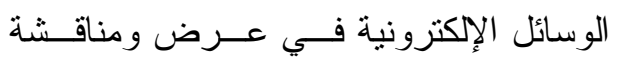

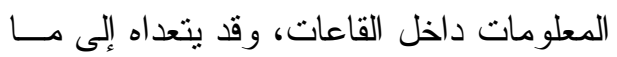
يسمى بالفصول الذكية التي تتم فيها العمليــة

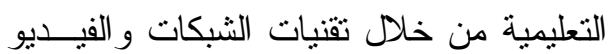

$$
\text { و غير ها(0). }
$$

ففي كل الأحوال فإن التعليم الإكتروني لا

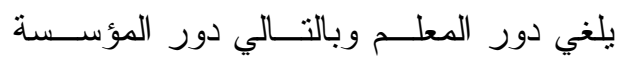
التعليمية ولكنه يعيد صياغة دور كل منهـــا.

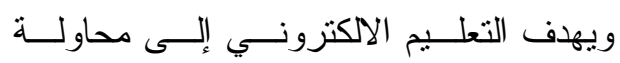
تعويض النقص الحاصل في أعضاء الهيئــة

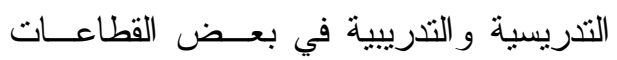

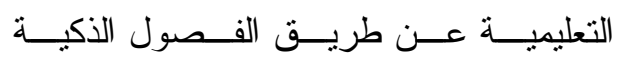

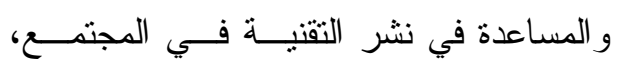
و إعطاء مفهوم أوسع للتعليم المستمر ، و إعداد

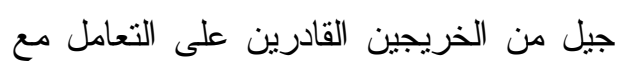
التقنية ومهار ات العصر و التطور ات الهائلــــة

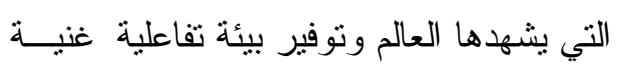
ومتعددة المصادر تخدم العملية التعليمية بكافة
التعليم وتمتد بما إلى مدى أبعد مـنـ نطـــاق

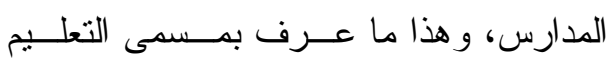
الإلكتروني الذي يعد من أهم ميزات مدرســــة

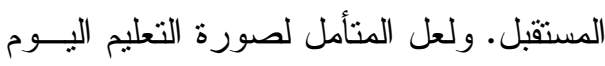
يجد أنها قد تغيرت عن عالم الأمس القريــب

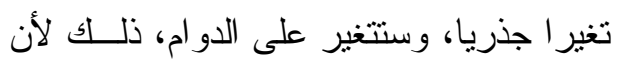

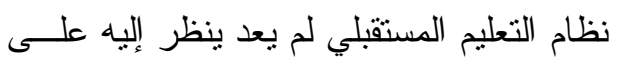

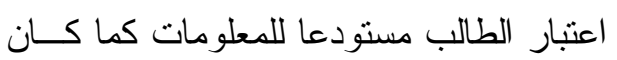

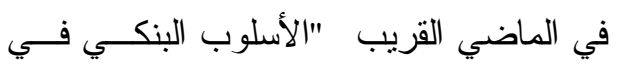

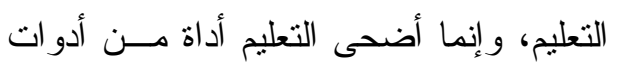

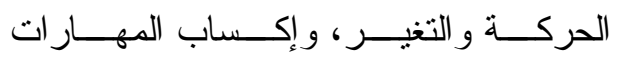
و الاتجاهات المختلفة التي تمكن الأفراد مــن ولن

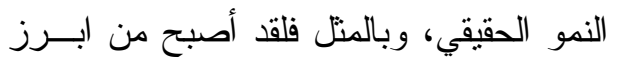
أغر اض التعليم اليوم تتمية الــوعي و الإدر الك الك

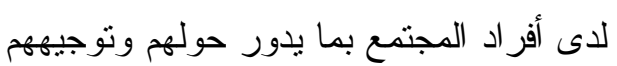

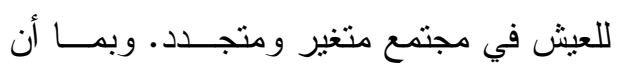

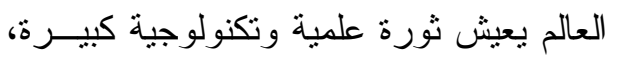

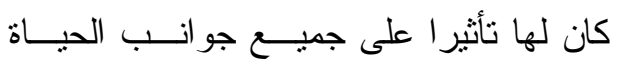

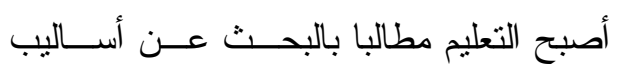

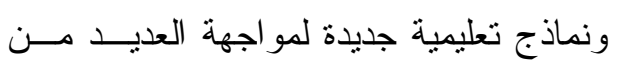

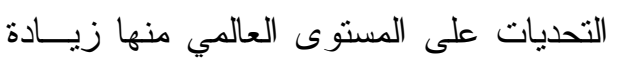
الطلب على التعليم مع نقص عدد المؤسسات

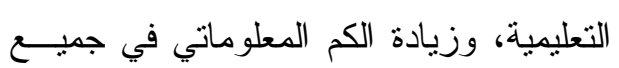

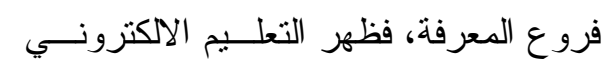
المساعد للمتعلم فـي (Electronic learning) التعلم في المكان الذي بريده وفي الوقت الذي 
المقصود هو استخدام التقنية بجميع أنواعهـا في إيصال المعلومة للمتعلم بأقصر وقت وأقل جهد و أكبر فائدة (؟)" كما أمكن تعريفه بأنه "برنـــامج تعليهـي وني

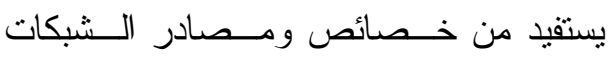
المحلية و العالمية، وما تتتجه من وسائط فائقة

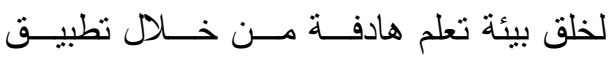

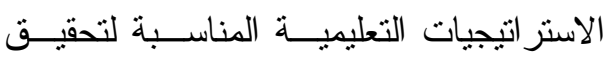
التعليم المعزز و المدعم، وهو بذلك يعد مثالا

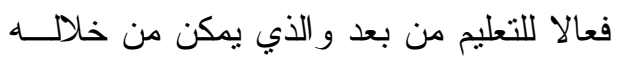

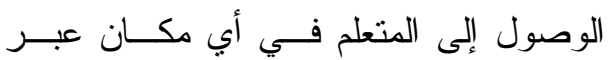
الثبكة، لكي يدرس في الوقت المناسب له (6)."

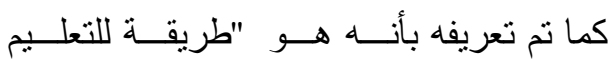

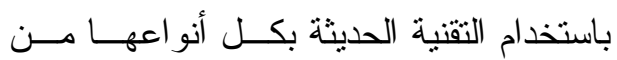
صوت وصورة ورسومات وبو ابات إلكترونية وذللك لتوصيل المعلومات إلى المتعلم في أقل ونل ونون

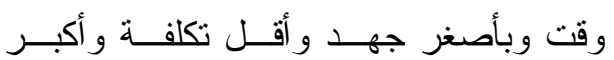
فائدة(9)". و وعرف التعليم الالكتروني بأنـــه "

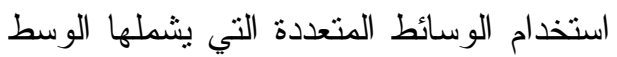
الالكتروني من ( شبكة المعلومــات الدوليــة

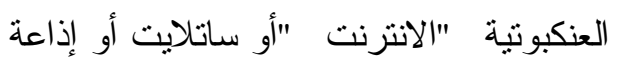
أو أفلام فيديو أو تلفزيون أو أقر اص ممغنطة أو مؤتمرات بواسطة أو بريد الكترونــي أو أو أوني محادثة بين طرفين عبر شــبكة المعلومــات الدولية ) في العملية التعليمية(·) (1)".

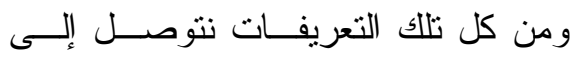
تعريف التعليم الإككتروني باعتباره "طريقــة
محاور ها وتعزيز العلاقة بين أوليــاء أمسـور الطلبة و المدرسة، وبــين المدرســـة و البيئــة

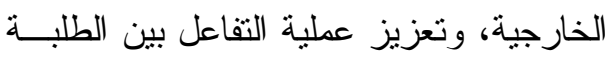
و المدرسين و المدربين، مــن خــلال تبــادل

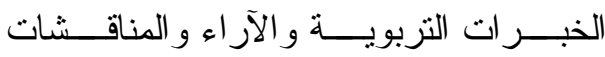

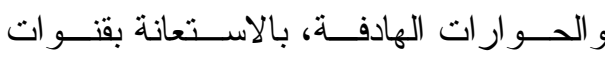

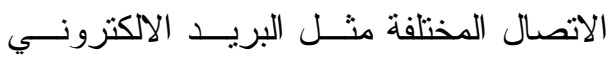
و الفصول الذكية. أن مفهوم التعليم الإلكتروني لئي مفهوم جديد نسبيا، وقد تطور ليشمل تلاقـي الئي

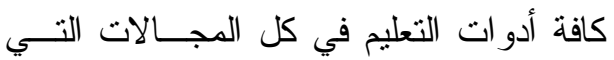

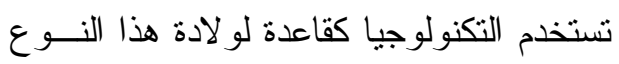
الجديد من التعليم، وقد بنيت فكــرة التعلـــيم الإككتروني حول فلسفة التعلم في أي مكــان و أي زمان، و التي تعني أن المتعلم يمكـن أن فئن

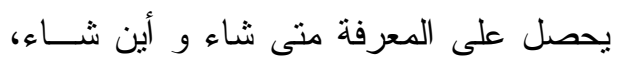
بمسنوى عال من الجودة ـ وحيال ذلك :لم يتم اتفاق كامل حول تحديد مفهوم شامل لمصطلح

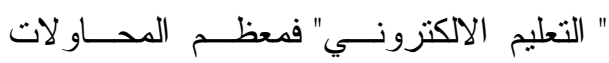
و الاجتهادات التي قضت بتعريفه نظرت كـــل

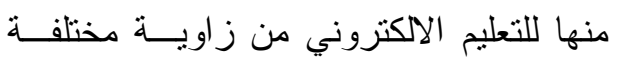

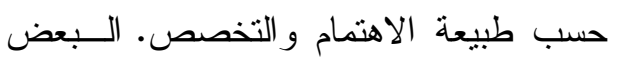
عرفه بأنه " طريقة للتعليم باســتخدام آليــات ولتهات

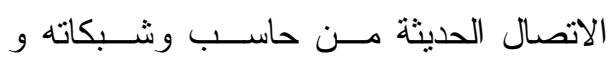

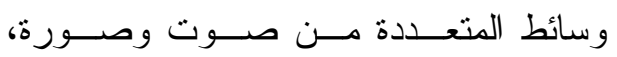

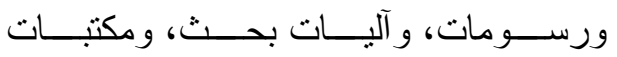
إلكترونية، وكذلك بو ابات الإنترنت سواء كان

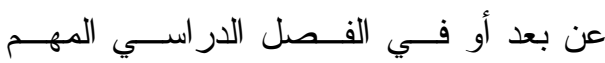




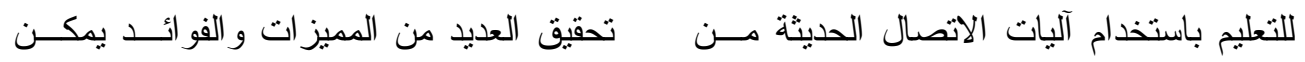

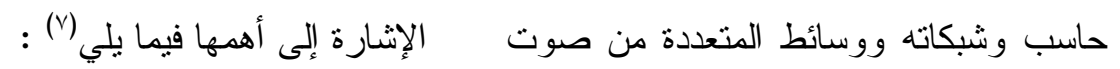

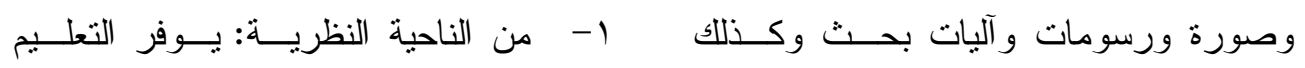

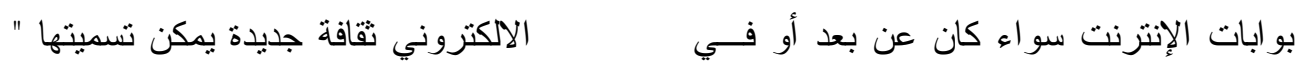

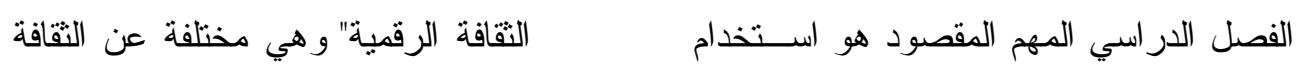

$$
\begin{aligned}
& \text { الثقنبة بجميع أنو اعها في توصيل المعلومسة }
\end{aligned}
$$

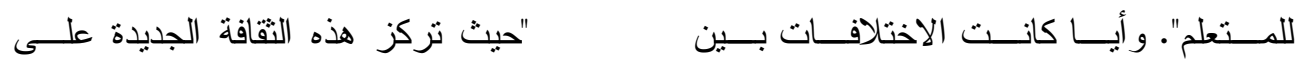

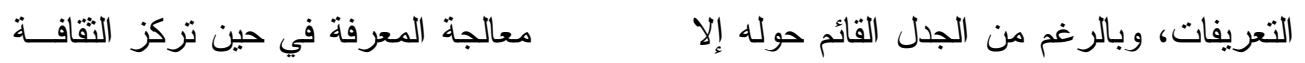

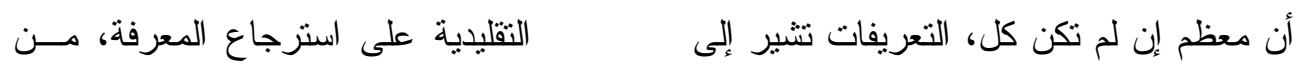

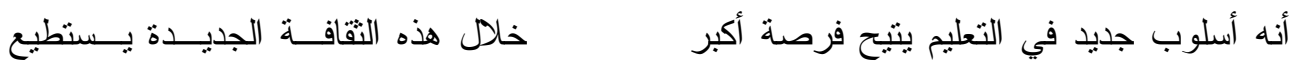

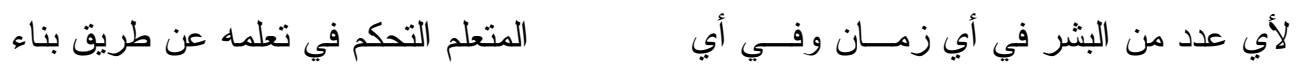

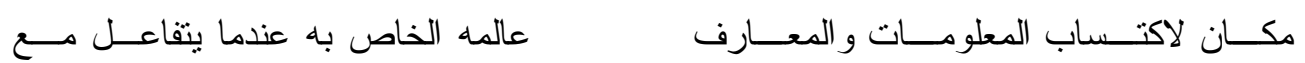

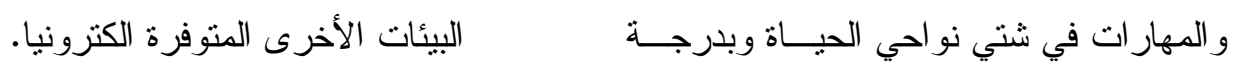

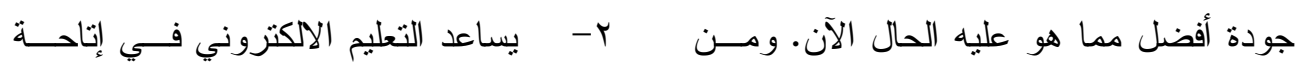

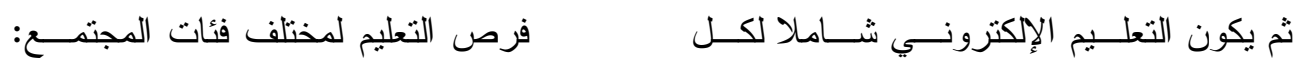

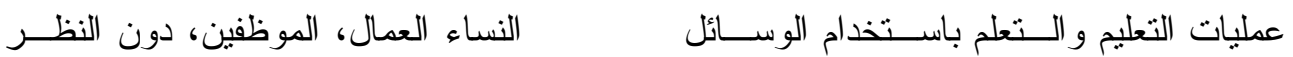

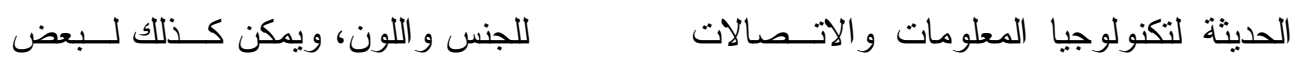

$$
\begin{aligned}
& \text { وكذلك دمج تللك الرسائل في الفصل الدراسي }
\end{aligned}
$$

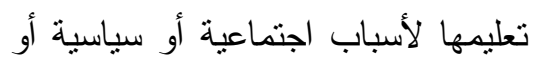

$$
\begin{aligned}
& \text { اقتصادية. وكـــللك مـشكلة الإعــداد }
\end{aligned}
$$

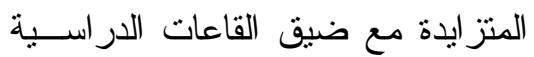

$$
\begin{aligned}
& \text { وقلة الإمكانات المتاحة. } \\
& \text { r- بتمبز التعليم الالكتروني بسهولة تحديث }
\end{aligned}
$$

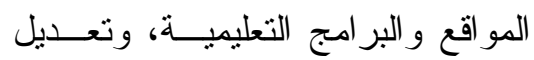

$$
\begin{aligned}
& \text { وتحديث المعلومسـات و الموضـــوعات }
\end{aligned}
$$

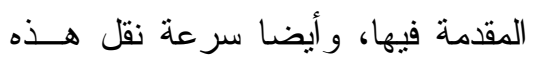

$$
\begin{aligned}
& \text { التقليدي كعامل مـسـاعد، ويـستخدم التعلــيم }
\end{aligned}
$$

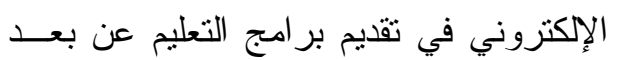

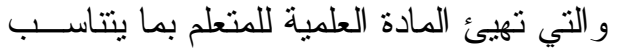

$$
\begin{aligned}
& \text { مع قدر اته وشخصيته، وكذللك إتاحة الفرصة } \\
& \text { للمتعلم للتفاعل حسب إمكاناته مع المعلم مسن } \\
& \text { خلا الفصول الذكية. } \\
& \text { (ب) مديزات وفو ائد التعليم الإلكترونسي. } \\
& \text { بالنظر و التمعن فــي المفهــوم الــشـامل } \\
& \text { للتعليم الإكتروني نجد أنه يمكن من خلالــهـ }
\end{aligned}
$$


• 1- إتاحة الفرصة للمعلمين بالاتصال مــع

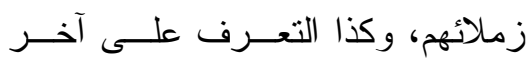
الإصدار ات في مجال المادة، مع تكوين

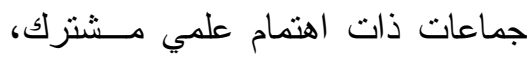
وتلقي التدريب مـن وســائط التعلــيم الالكتروني ومسـساعدتهم فــي إجــر اء البحوث وتبادل المعلومــات، وتعيـين وهين مهار اتهم وتوجيه مطالبهر.

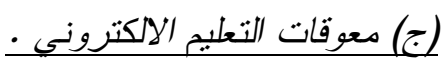

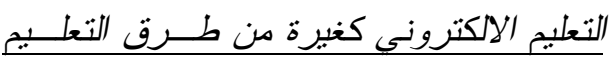
الأخرى لليه معوقات تعوق تنفيذه و من هذه الاهير العو ائق ("). لأنزي

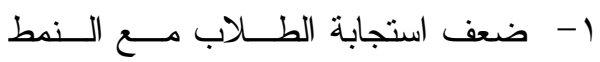

$$
\text { الجديد وتفاعلهم معه. }
$$

r- عدم وعي أفر اد المجتمع بهذا النوع من معهن

$$
\text { التعليم و الوقوف السلبي منه. }
$$

ץ- زيادة التزكيز على المعلــم و إثثــعاره

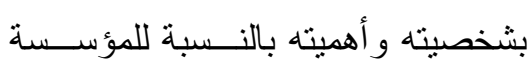

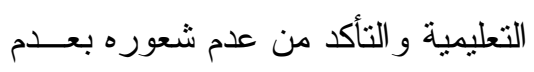

أهميته و أنه أصبح شيئا ثر اثيا تقليديا.

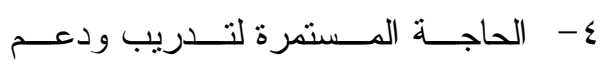
المتعلمــين و الإداريـــين فــي كافـــة المستويات، حيث إن هذا النــوع مــن التعليم يحتاج إلى التذريب المستمر وفقا

$$
\text { لتجدد التقنية. }
$$

0- - الحاجة إلى تدريب المتعلمــين لكيفيــة التعليم باستخدام الإنترنت.
المعلومات إلى الطلاب بالاعتماد على الانترنت. ع- - تصميم المادة العلميــة اعتمــادا علــى العـ

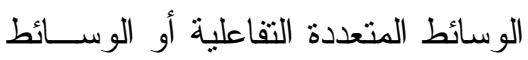
الفائقة ( صوت، صورة، أفلام، صور

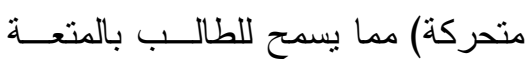
و التفاعل و الإثارة و الدافعية للتعليم. 0- تعدد مصادر المعرفة نتيجة الاتـصال بالمو اقع المختلفة على الانترنت. 7- مر اعاة الفروق الفردية لكل متعلم نتيجة لتحقيق الذاتية في استخدام جهاز واحد

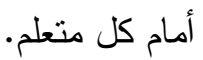

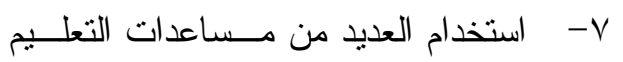
و الوسائل التعليمية و التي لا نتوفر لدي لدي

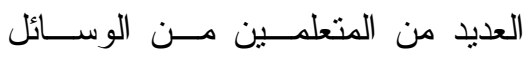
السمعية و البصرية.

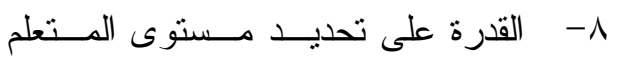
و إيصال المحتوى المناسب بدون التقيد

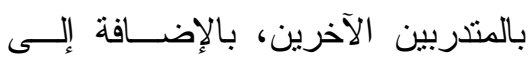
سهولة التعرف على المر احل الــسابقة بالإنة التي اجتاز ها المتعلم. 9 - يسمح بتــميم وبنـــاء الاختبــار ات

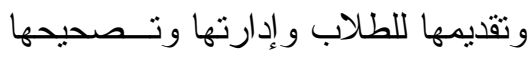

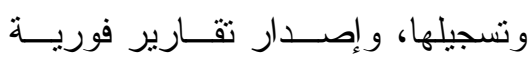
وشاملة لحالة الطالب، و مدى تقدمــهـ واصله

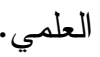


التقليدي، ويخرج هذا النمــوذج خــارج

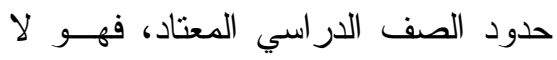

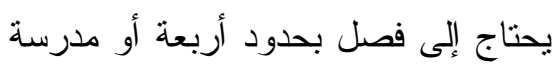
ذات أسوار، بل يتم التعلم في أي مكــان

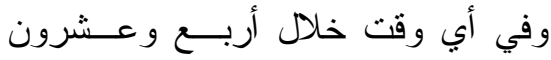

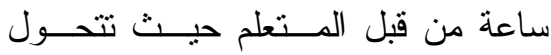

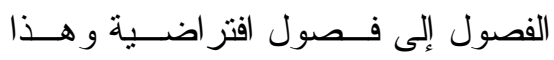

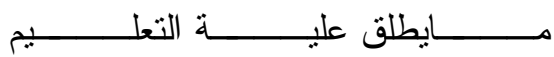
الافتر اضي"VIRTUAL LEARNING" ويتم في مدارس وجامعات افتر اضية، وهــــ إحدى صيغ التعلم الالكتروني عن بعـــــ

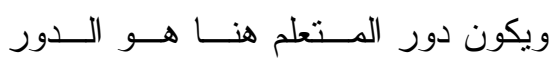
الأساسي حيث يتعلم ذاتيا بطريقة فرديــة دونة على حدة أو بطريقة تعاونية مع مجموعة

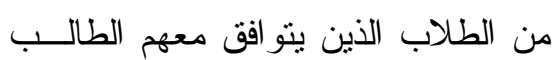

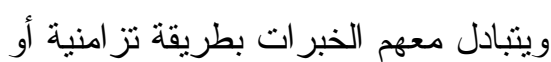
غير تزامنية عن طريق غرف المحادثة، مؤتمرات الفيديو، السبورة الذكية، البريد الالكتروني، مجمو عات المناقشة. r - النمط الثاني: أن بكون مصدر جزئسـي:

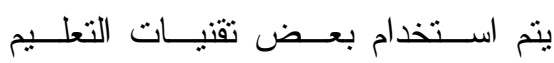

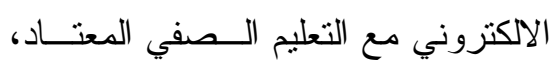
وقد يتم أثثاء اليوم الدر اسي في الفصل أو لوني خارج ساعات اليوم المدرسي ومن أمتلة هذا النموذج : توجيه الطلاب إلى إجر اء بحث بالرجوع إلى الانترنت أو قيام إدارة

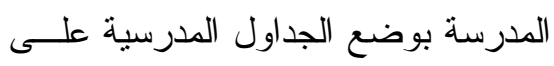

צ- تعديل كل القو اعد القديمة التي تعــوق

الابتكار ووضع طرق جديدة نـنـهض

بالابتكار في كل مكان وزمــان للتقــدم

بالتعليم و إظهار الكفاءة و البر اعة.

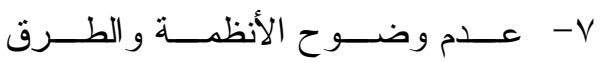

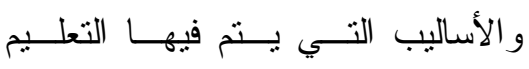
الإلكتروني بشكل فعال.

- - الحاجة إلى بنية تحتية صلبة من حيــث

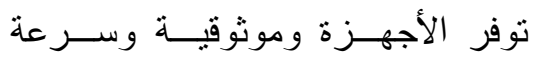
الاتصال بالثبكة العالمية للمعلومات.

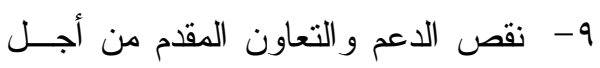
طبيعة التعليم الفعالة. • 1- فقدان العامل الإنساني في التعليم.

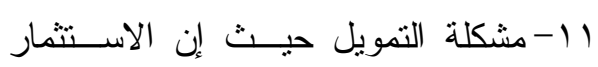
المبدئي لإنشاء شبكة المعرفة وتجهيـز المدارس بالإضافة إلى تكلفة التششيل لتشيل

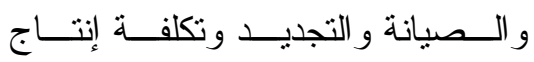

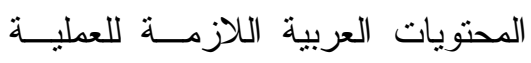
التعليمية نتكل تحديا حقيقيا.

ثانيًا : أنعاط استخدام التعليم الاككتروني في العملية التعليمية وأساليبه وتقنياته

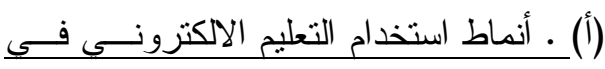
العملية التعليمية.

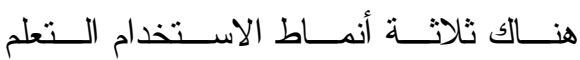
الالكتروني في التعليم هي (rع): 1- النمط الأول : أن يكون مصدر شامل : يستخدم التعليم الإلكتروني بــديلا للــتعلم 
عملية الجمع بين التعلم التقليدي و الــتـعلم

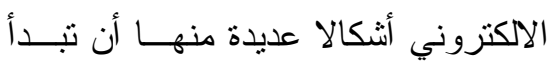

المعلمة بالتمهيد للارس ثم توجه المعلمة

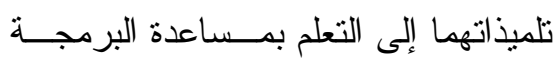

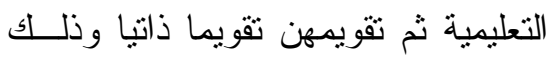

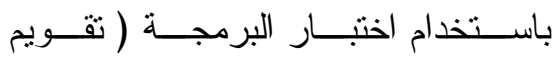

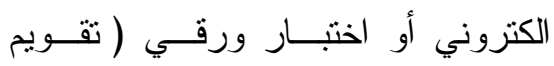

تقليدي)، وقد تبدأ عملية التعلم التقليــدي

لبعض الدروس التي تتتاسب معه و التعلم

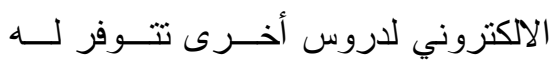

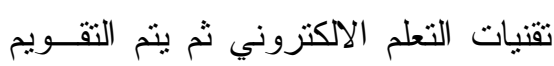

بأحد الثكلين التقليدي أو الإككتروني.

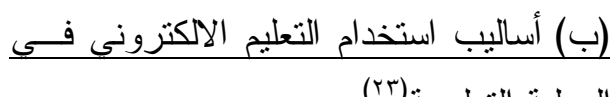

العملية التعليمية(rr).

أن الدمج الصحيح بين التعلــيم التقليــدي لــي

و التعليم الالكتروني يعتبر أفضل من التعلــيم

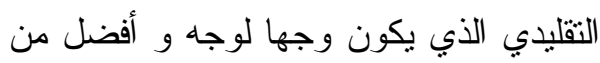

التعليم الالكتروني إذا كان كل منهما منفصل ونها وله

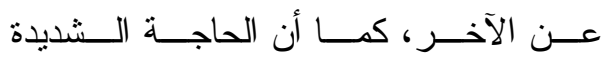

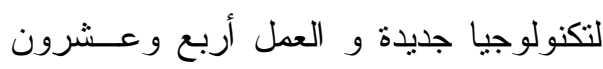

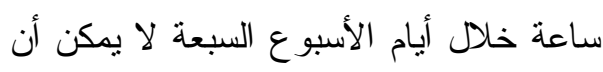

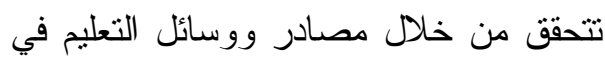

الفصل العادي و التعلم المختلط يحقق كل هذه

الأشياء من أجل نطوير حاجات المتعلم، كما

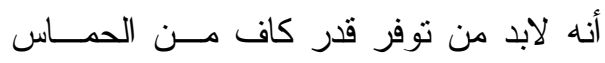

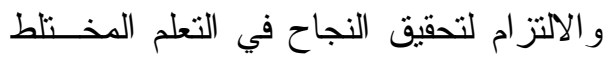

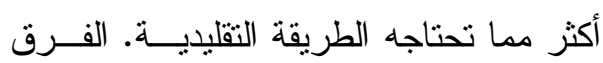

أحد مواقع الإنترنت أو استفادة المعلم من الإنترنت في تحضير دروسه وفي تعزيز

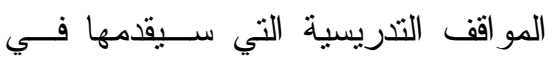
الفصل التقليدي.

r- النمط الثالث : أن يكون مصدر ا مكملا.

ويتضمن هذا النموذج الجمع بين الــتعلم

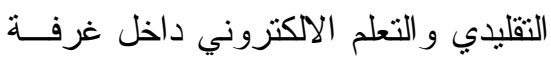
الصف أو في معمل الحاســوب أو فــي

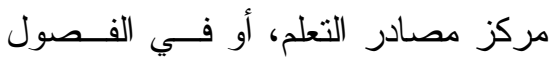

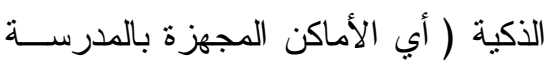

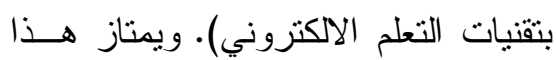

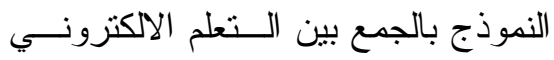

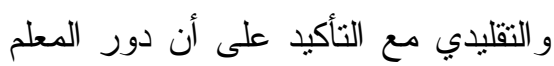

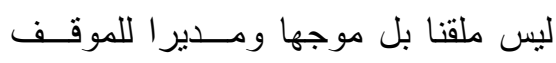
التعليمي، ودور المتعلم هو الأساس فهو يلعب دورا ايجابيا فـي عمليــة تعلمــهـ.

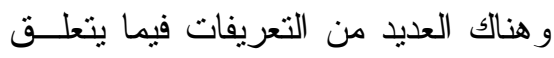
بالتعلم المختلط وتجمع على أنه الجمــع بين عدة أنماط من التعليم، مثتـل الــتعلم

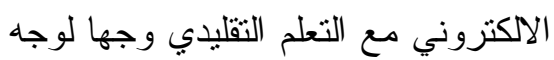

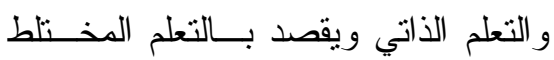

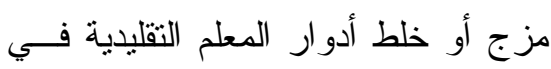
الفصول الدراسية التقليدية مع الفـصول الذكية، أي أنه تعلم يجمـــع بــين الــتعلم التقليدي و التعلم الالكتروني. إذا هو الذي

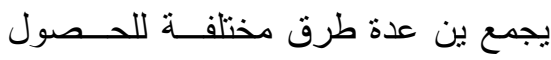

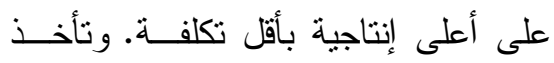


في نقل المعرفة إلى الطالبات في نظام التعليم الاككتروني. أساليب التعليم الالكتروني.التعليج الالكترونسي بقدم أسلوبين من التعليم: -Synchronous

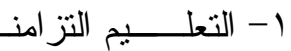
.Learning

و هو التعليم على الهواء الذي يحتاج إلى

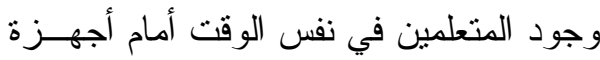

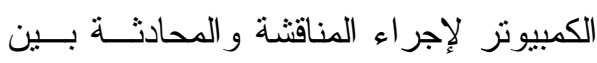

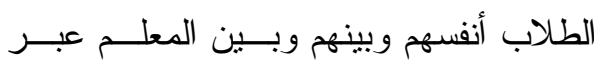
غرف المحادثة (Chatting) أو تلقي الدروس ولف Virtual من خلال الفـصول الافتر اضــية .classroom

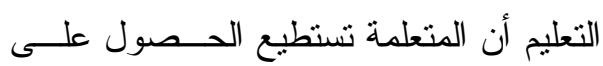
التغذية الر اجعة المباشرة من المعلمــة فــي الوقت نفسه (v). -Asynchronous r- التعليم غير التزامنـي لوني .Learning و هو التعليم غير المباشر الذي لا يحتــاج إلى وجود المتعلمين في نفس الوقت أو فـي لفي لفي نفس المكان، ويتم من خلال بعض تقنتيـات

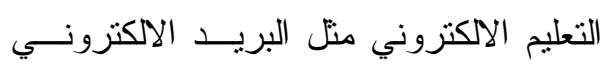

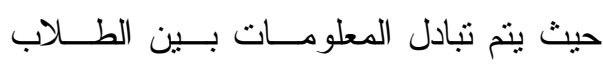
أنفسهم وبينهم وبين المعلم في أوقات منتالية،

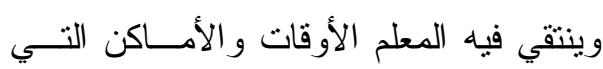
تتاسبه (9) (9)

$$
\text { ولقد جمعت الثبكة العنكبوتية العالمية }
$$
(www.world wide web)
بين التعليم الالكتروني و التعلــــم التقليــدي. توجد مجموعة من الاختلافات و الفروق بين كل من التعليم التقليدي و التعليم الإككترونــــي لوني التي تعتبر من الخصائص المميزة لكل منهم

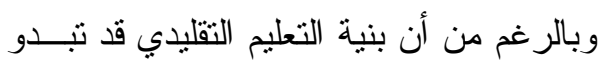
في عمومها حو اجز أمام التعليم الإككترونــي لئي إلا أن الدمج بين التعليم التقليدي إلى التعلـــيم

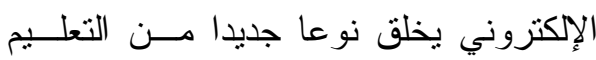
الموزع الذي يهدف إلى إثراء وزيادة فعالية

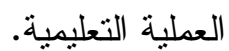

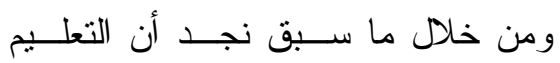
التقليدي و التعليم الالكتروني يتفقان في الغاية ويختلفان في الوسيلة. فغاية هذين النــوعين من التعليم تتمنل في الحصول على مخرجات على مستوى عال تتميز بالمعرفة المتقدمسـة فئس

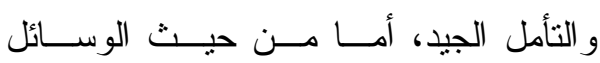

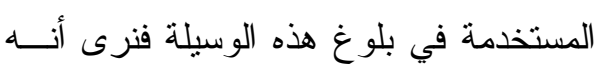

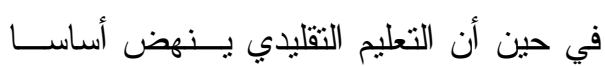

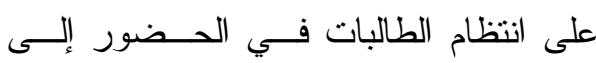
قاعات الدراسة لتلقي العلم من معلمة تستعين

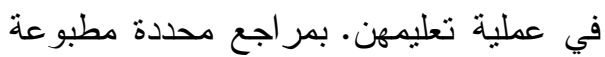

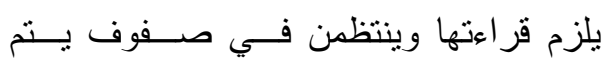
تحديدها وفقا لأعمار هم، ويتم انتقائهم وفقـــا

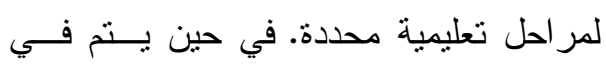
التعليم الالكتروني تلافــي إثـــكالية انتظــام

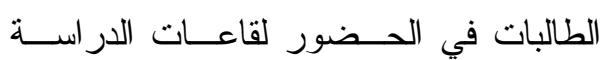
بصورة منتظمة، وتتتوع الوسائل المستخدمة 
( ثالثا ) طبيعة ومتطلبسات تُقيق الفصول الذكية Smart Classes

نحن نعيش في القرن الحادي و العـشرين

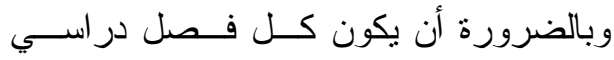
مناسبا للبيئة الدراسية التي يتطلابهــــا القــرن

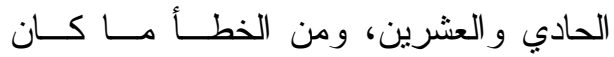
المعلمون يهتمون فيه باستخدام وسائل القــرن

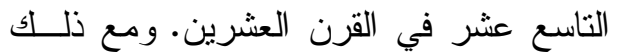
لاز ال كثثر من المعلمين متمسكين بالوســائل

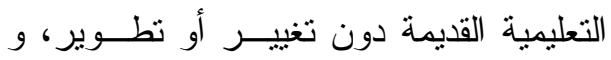
قبول فكرة التجديد و التطوير يعني أن التقنيــة لفيـة

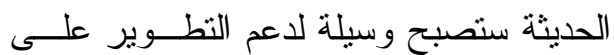

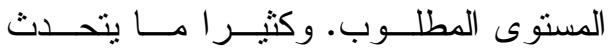
التزبويين عن الفصل الدراسي في المسـتقبل، كيف سيكون؟ وما هي التقنيات المكونة لــه؟

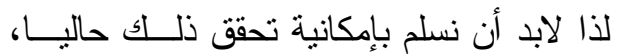
فالعو امل المعينة على إيجــاد بيئــة مــزودة بالتقنيات الحديثة التـي ســتو اكب منطلبــات القرن الواحد و العشرين منوفرة اليوم. وعلى الرغم من استخدام الإنترنت و التعليم عن بعد إلا أن هناك مكونا ثانويا مهما يحتــاج إليـــه

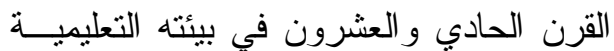
ألا وهو تطوير وتنبني مستويات قــادرة فــي

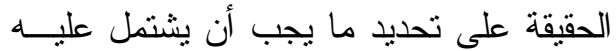
الفصل التعليمي في القرن الحادي و العشرين.

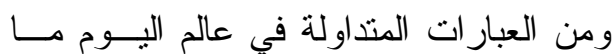
يسمى (بالفصول الذكية) هذه الفصول لــديها

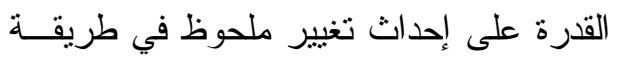

و التعليم غير التز امني، فالتعليم يتم في كـلــ

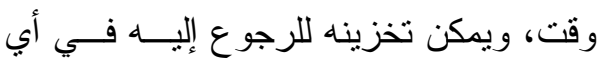

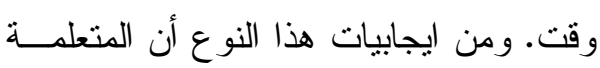

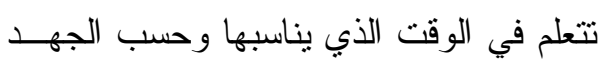

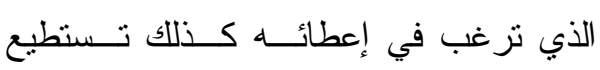
المتعلمة إعادة در اسة المادة و الرجوع إليهــــا الكترونية كلما احتاجت لذلك. أما الــسلبيات عدم استطاعة المتعلمة الحصول على التغذية

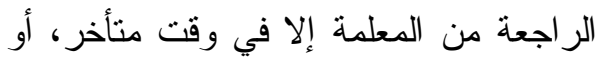

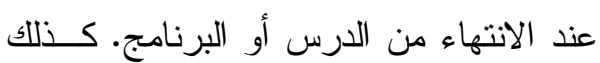

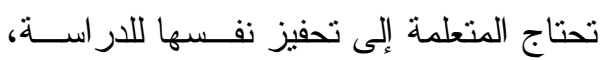
وذلك لان معظم الدراسة تقوم علــى الــتعلم الذاتي (') (ج) تقنيات استخدام التعليم الالكترونسي فـي العملية التعليمية.

يرتكز التعليم الالكتروني على مجموعـــة من المصادر الحديثة ومن أهمها(ه):

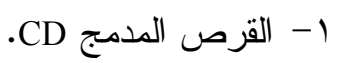
r- ب الثبكة الداخلية. r- شبكة الإنترنت. ع - مؤتمر ات الفيديو .

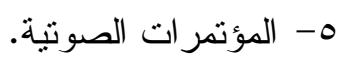
7- الفيديو التفاعلي.

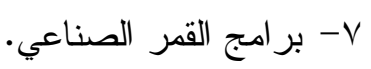
1- الفصول الافتر اضية. 9- الفصول الذكية ( الاككترونية) 
المعلومات و الاتصالات وتطور ها المـستمر و المذهل خلد الــسنوات القليلــة الماضـــــة

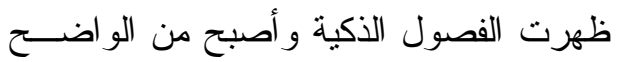

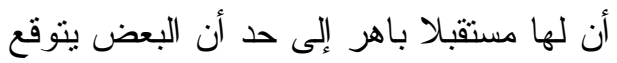

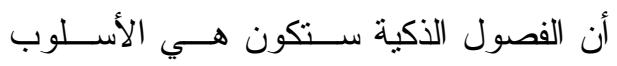

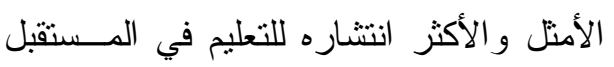

$$
\text { القريب. - (القاب }
$$

(أ) المقصود بالفصول الذكية.

تتعدد تعريفات الفــصول الذكيــة حيــث تعرف بأنها عبارة عن مجموعة من الأنشطة

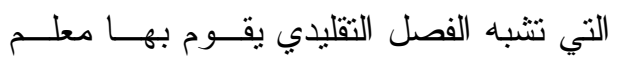
وطلاب تفصل بينهم مسافات مكانية شاســعة

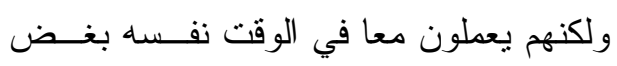

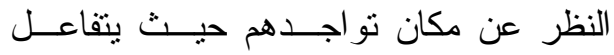

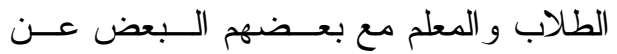

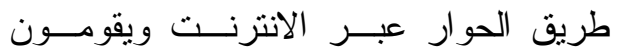

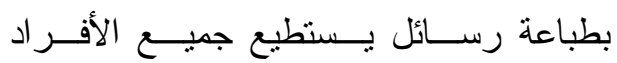

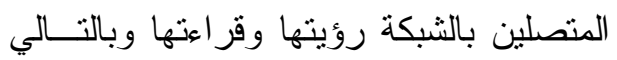
فهمها و التفاعل معها. بينما يشير إليها البعض وته

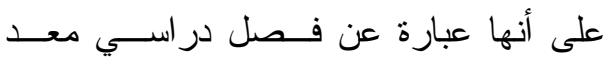

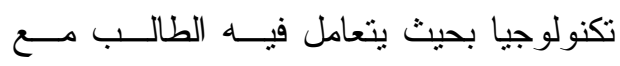

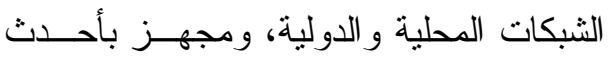
مصادر التعلم و المناهج و المقرر ات الموجودة

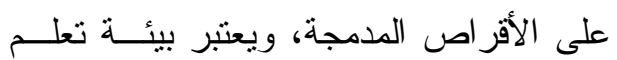

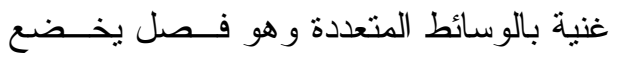
الإشر اف المعلم وتوجيهه الدائم(r').
إلقاء المعلمين لدروســـهم وكيفيــة معالجـــة

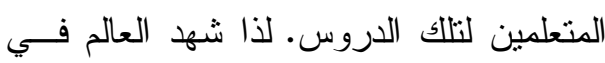

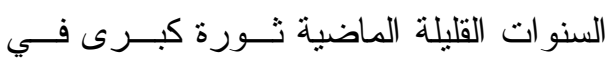
تكنولوجيا التعلــيم. حيــث اتسـع اســـتخدام الحاسبات و البرمجيات و الانترنت في تعلــيم

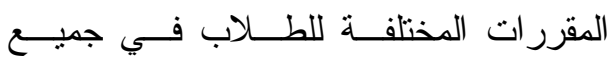
المر احل. وظهرت الفصول الذكية و انتشرت في رحاب العديد من جامعات الدول المتقدمة.

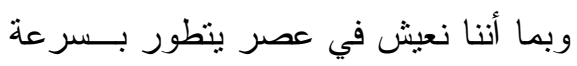

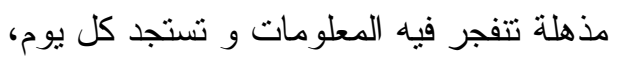

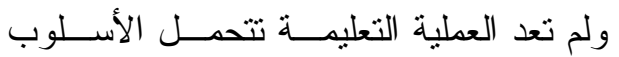
التقليدي التي تسير عليه مؤسساتتا التعليميــة،

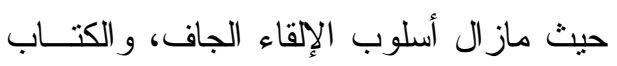

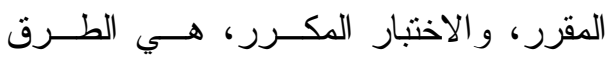

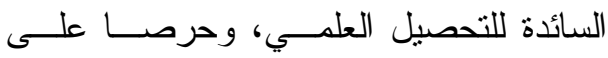
النهوض بالعملية التعليمة و الخروج بما مـنـ وحن إطارها التقليدي أولت معظم وزارات التربية و التعليم في أكثر دول العالم جل اهتمامها في وضع الاســنز اتيجيات الخاصــة باســتخدام الحاسب الآلي و الانترنت و الاستفادة منهما في مجال التزبية و التعليم (1')

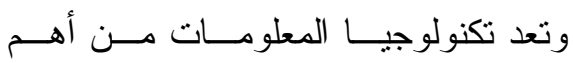

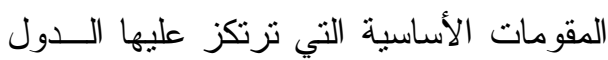

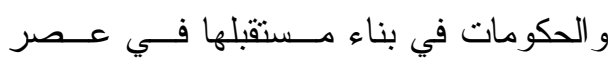
المعلومات و الإلكترونيات الذي نعيشه اليــوم

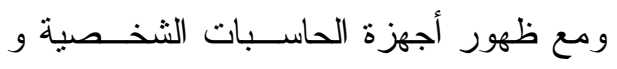

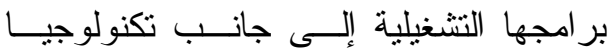


ويمكن تعريفه بأنها "عبارة عـن غرفــة (ب) مراحل التخطبط الاســتخدام الفـصول

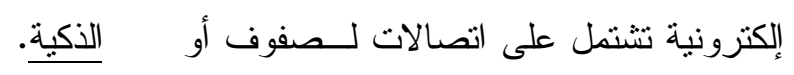

تعد مر احل التخطيط الاستخدام الفصول

أماكن خاصة يوجد فيها الطلاب، ويرنبط علئنون

الذكية: كما هو الحــال مــع أي مـستحدث

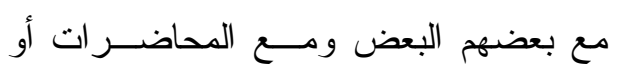

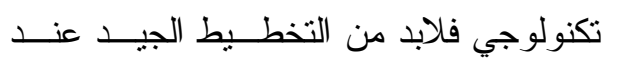

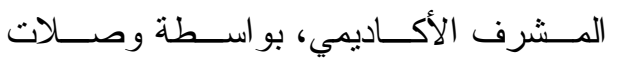

توظيف و استخدام ذلك المـستحدث و وإتبــاع

و أسلالك أو موجات قــيرة عاليــة التــردد

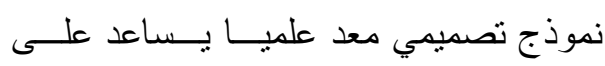

تزتبط بالقمر الصناعي الخاص بالمنطقـــة أو

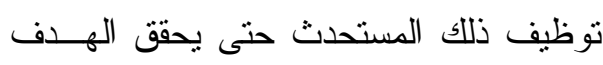

شبكة الانترنت(V). ويعرف (مكتب تكنولوجيا

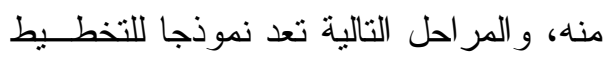

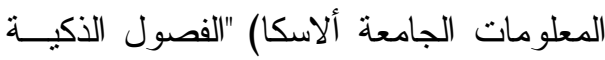

$$
\text { الاستخدام الفصل الذكي (·): }
$$

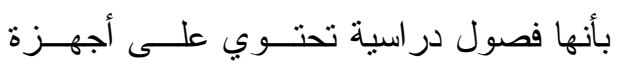

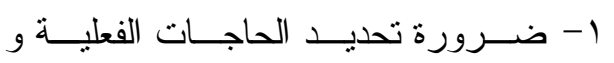

مبرر ات الحاجة لتلك الفصول الذكية.

r- تقدير التكلفة المادية لإنــشاء الفـصول مبرل

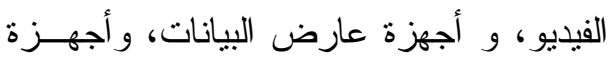

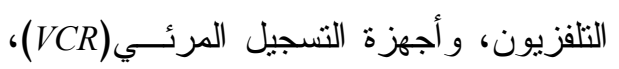
ومشغلات (DVD)، و الكمبيوتز ات، و الثبكات

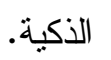

ب- تحديد الجهود التي سوف تبــنل لإنــشاء

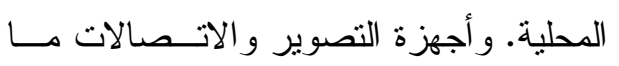

$$
\text { الفصول الذكية. }
$$

بين الفصول المختلفة(r)".

ع - در اسة المــستجدات اللازمـــة و الآثــار

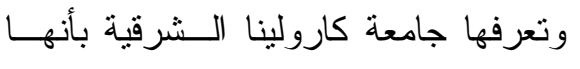

$$
\text { المتزتبة من إنشاء هذه الفصول. }
$$

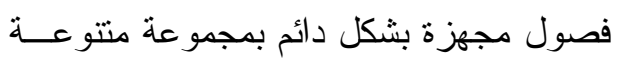

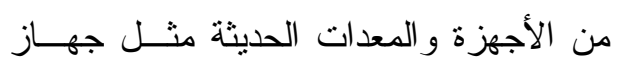
0- وضع خطة تصميم الفصل الذكي.

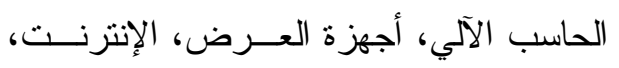
צ- تتفيذ وتصميم الفصل الذكي.

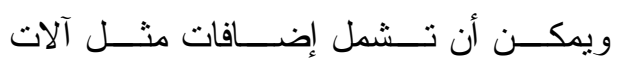
- V تقييم أساليب الطلاب في استخدام الفصل

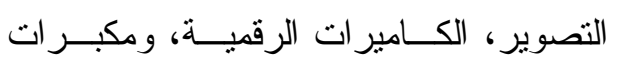

$$
\text { الذكي. }
$$

1- تثنيت نظام الفصل الذكي.

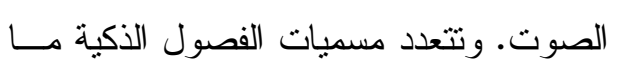
9- صيانة الفصول الذكية.

بين الفصول الاعتبارية، والفــصول الآليــة

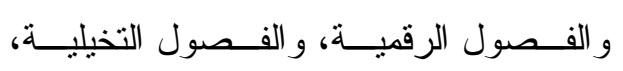

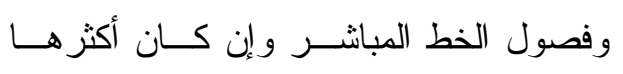
انتتار و استخداما هو الفصول الإككترونية(ه). 
الثرائح، جهاز عـرض أثـــرطة الفيــيو و التلفزيون، ومسجل وجهاز عرض الأفــلام وأجهزة نتغيل اسطوانات الفيديو ومؤشرات

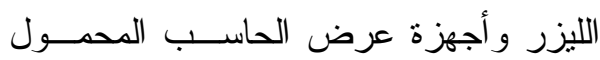
و غير ها من أجهزة العرض المرئي وينبغــي توفير ها لهم عند الطلب.

كما تعد الفصول الذكية فصو لا مــزودة

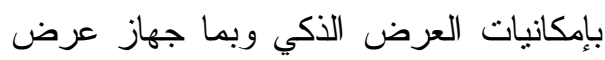
أثنرطة الفيديو وجهاز عــرض المعلومــات و الصور ومنبر ولوحة تحكم فـي الوســائل

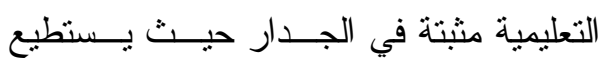
المقدم عرض مخرجات الحاسب على شاثة كبيرة وبه جهاز عرض للـشر ائح وجهـاز العرض العلوي.

و علي صعيد أخر ينظر للفصول الذكيــة باعتبار ها فــصو لا ذات حاسـبـات تفاعليــة interactive computer classroom كل طاولة عمل فيها على جهـاز حاســب، كابل

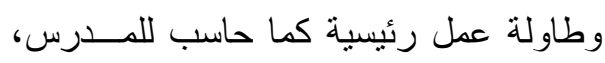
و إمكانية العرض من داخل أجهزة الطــلاب

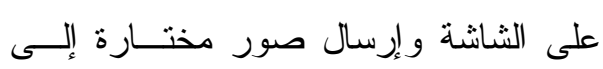

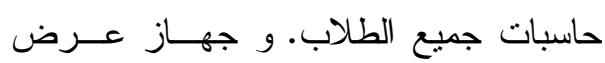

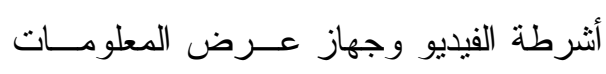
والصور، و جهاز عرض الثرائح وجهــاز

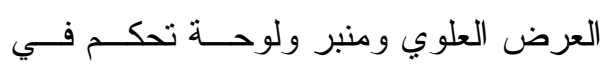
الوسائل التعليمية مثبتة في الجدار • ويستطيع

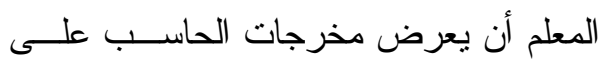

(ج) العلاقة بين الفصول الذكيــة و الفــصول التقليدية ومستوياتها

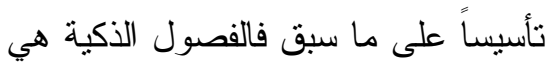

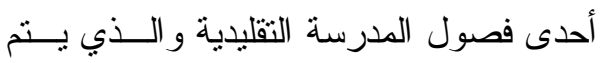
تجهيز ها بوسائل الاتصال الحديثة لتحويلهـا

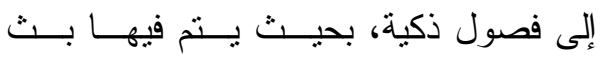
و استقبال المقرر ات الدر اسية باستخدام وسائل

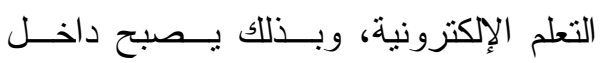

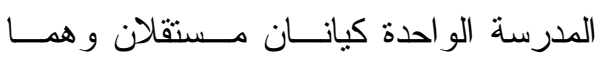
الفصل التقليدي و الفصل الذكي ولكل مــنهم فلسفته الخاصة، ولكن يتم استخدام كل منهم

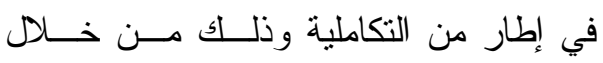

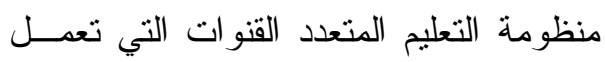

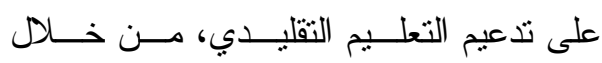

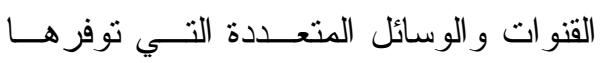

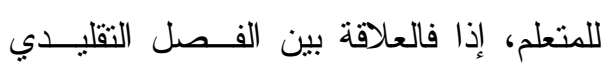
و الفصل الذكي هي علاقة تكاملية.

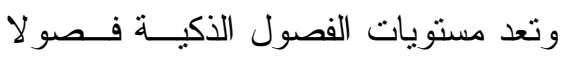
مزودة بجهاز تلفزيون وجهاز عرض فيـديو وشاثنات وجهاز عرض الــشرائح وجهــاز

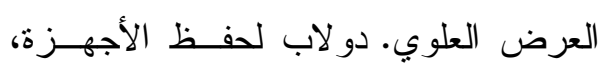

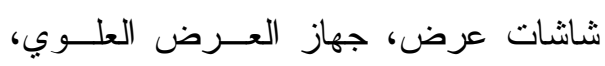
تلفزيون وجهاز العرض على شاشة كبيــرة، جـان

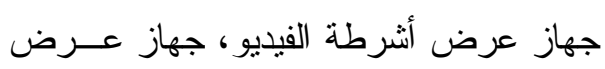

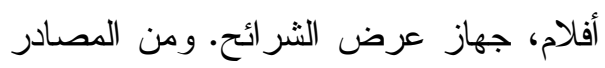
التي بطلبها الأساتذة في الفصل: السبور ات،

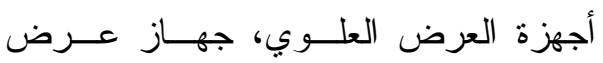




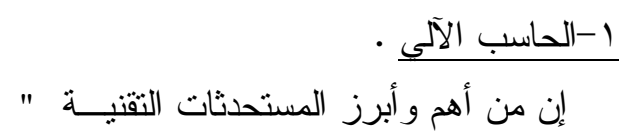
ذلك المولود الضخم الذي أنجبنه الثورة الثقنية و العلمية ليغير من معالم الحياة بكاملها في هذا

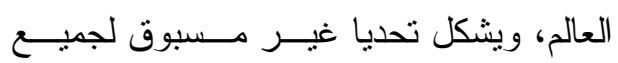

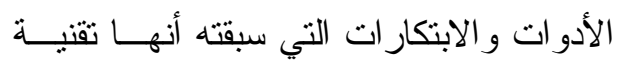
الحاسوب أو ما يسمى بالعقول الالكترونيـــة.

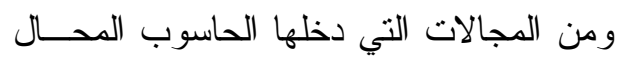

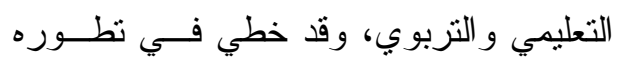
خطو ات و اسعة،، محدثا ثورة علــى أســاليبه وممارساته التقليدية في كيانه وفي كمه، وكيفه

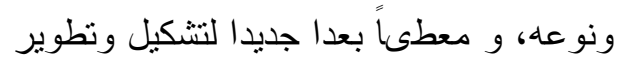

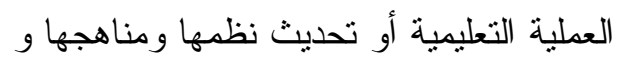
و آلياتها وطر ائقها وأساليبها ومقدما لها العديد من الخامات، وقد ظهر نتيجة لذلك شعور عام ولمان

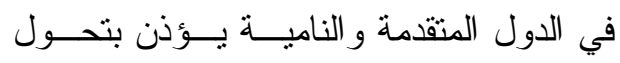
المجتمعات العالمية إلى مجتمعات محوسبة.

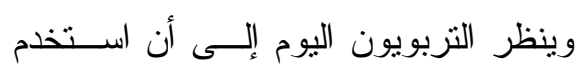

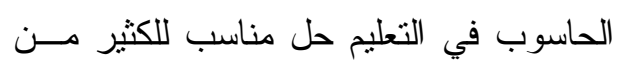

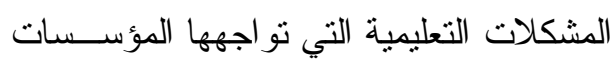
التربوية و التعليمية، ووسيلة ناجحة لتحسـين

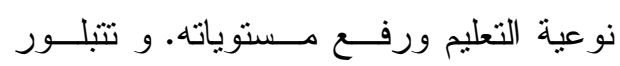

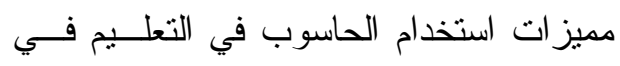

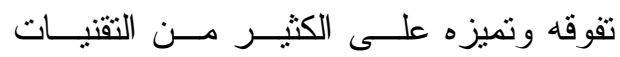

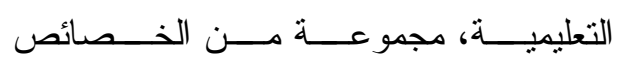
و الإمكانات التي لا تتو افر مع غيره، ويــأتي

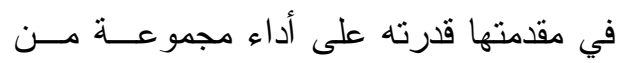

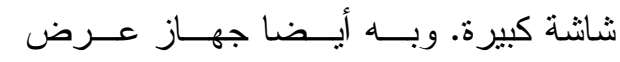
الشرائح وجهاز العرض العلوي.

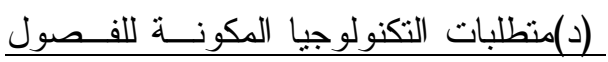
الذكية.

أن الفصول الذكية هي فــصول دراسـية

تتيح توفير فرص جديدة في التعلــيم و الــتعلم عــن طريــق دمــــج الــشبكات الرقميـــة،

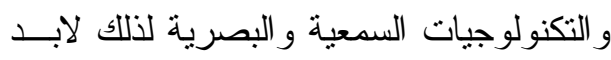

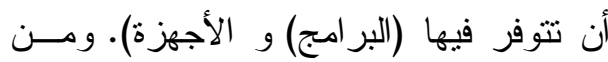

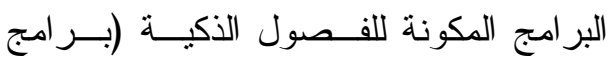

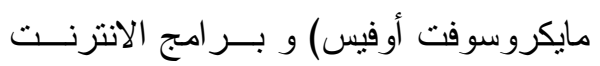
(Internet Explorer) (Real Player ،Media Player ( جهاز الحاسب الآلي، آلة التصوير، سبورة

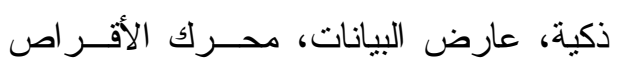

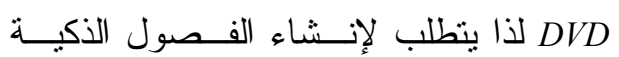
وتحويلها من تقليدية إلى ذكية عدة عناصــر

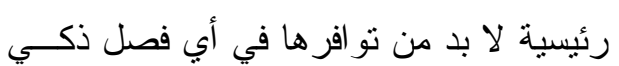

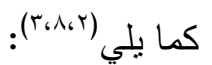

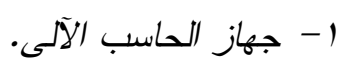
r- الانترنت. r- الثبكة المحلية. ـ- البرمجيات. - أجزةة العرض. 1- السبورة الذكية. 
دواعي ومبررات استخلام الحاسوب في التعليه :

توجد العديد من الأسباب و المبررات التـي

تدعو استخدام الحاسوب في التعليم وهي (؟): • الانفجار المعرفي وتتدفق المعلومات: حيث يسمى هذا العصر بعصر السرعة، وخاصة

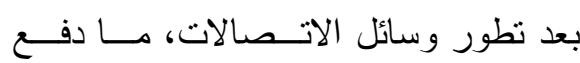
الإنسان إلى الدراسة عن وسيلة لحفظ هذه

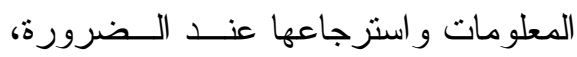
وظهر الحاسوب كأفضل وسيلة تؤدي هذا الغرض.

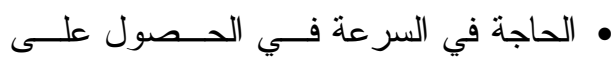
المعلومات: وذللك لأن هذا العصر عـــر فـر ثورة المعلومات، مما يجعل الإنسان بحاجة

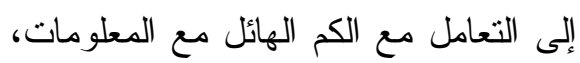
وكلما كان ذللك بأسرع وقت و اقل جهذ فانه

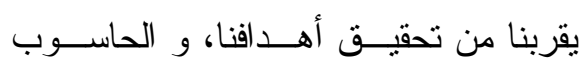
أفضل وسيلة لذلك حتى الآن.

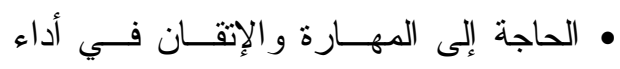

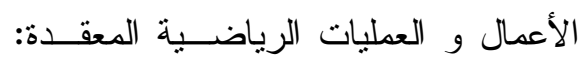
حيث يتميز الحاسـوب بالدقـــة والإتقــان

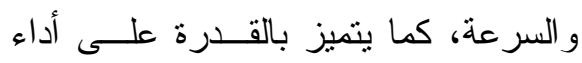
جميع أنواع العمليات الحسابية المعقدة كلما بلميز بال تو افرت البر امج اللازمة لتحقيق ذلك.

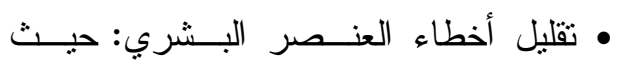
يستطيع الحاسوب أداء أعمال مجموعة من الأيدي العاملة الماهرة في الإعمال الإدارية

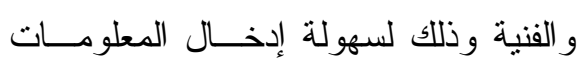

المهام لتقتيات متعددة في وقت و احد. جامعــاً بين الصوت و الــصورة و الحركـــة و اللـــــن و إمكانية التفاعل المباشر وغير المباثر عندما

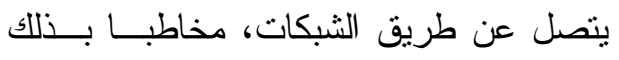
معظم حواس المتعلم. و الحاسوب أداة جيــدة

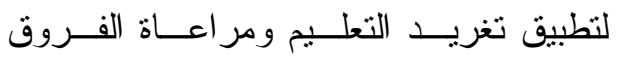
الفردية، وتزود المتعلم بتغذية راجعة فورية.

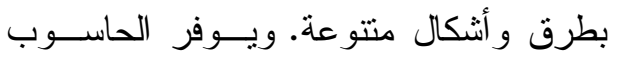

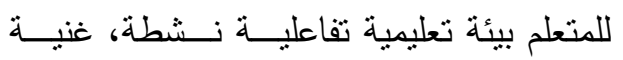

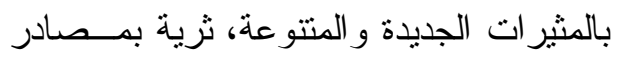

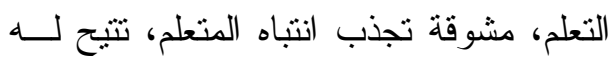
المغامرة و الاكتشاف و التجريب و التقكير دون

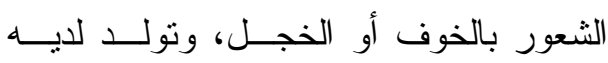
الرغبة و الدافعية القصوى للتعلم و الإقبال على ولى

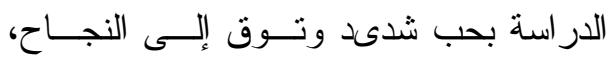

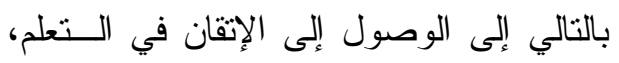

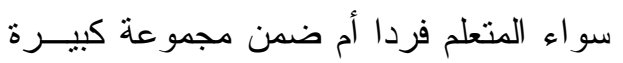
من المتعلمين. لذلك فالغرض مــن اســـتخدام

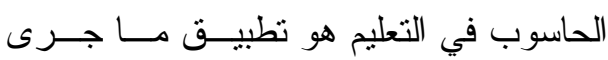

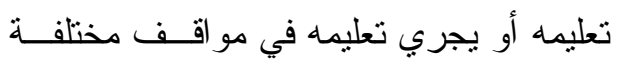

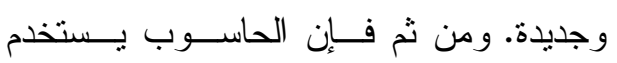

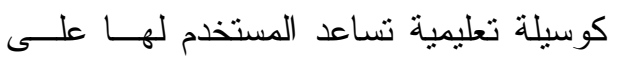
اكتثاف موضو عات جديدة ومختلفة عما قـام بدر استه بالإضافة إلى اكتشاف طرق للإجابة عن سؤال محدد. 


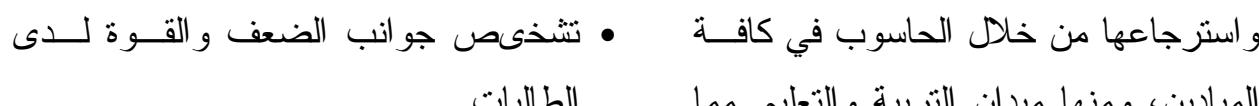

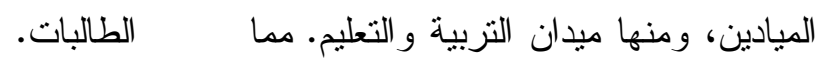

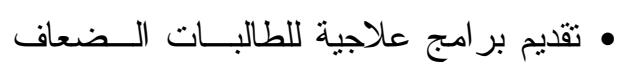
يساعد على تقليل الأخطاء أو تلافيها.

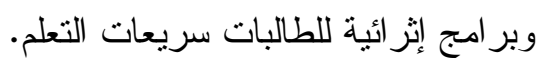
• متابعة تعلم الطالبة و بشكل مستمر .

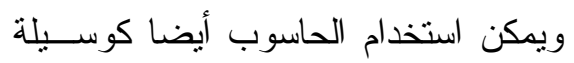

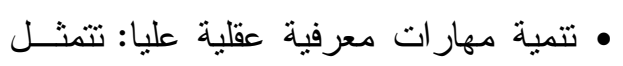

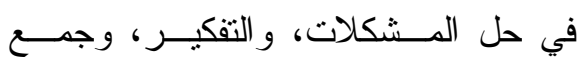

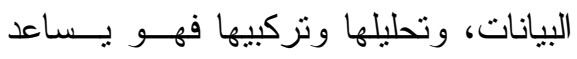
للتحكم بالوسائط التعليمية المختلفة للربط بين

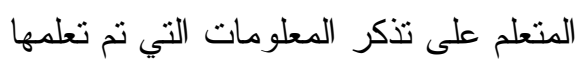
الأجهزة السمعية و البصرية المختلفة مثنـل:

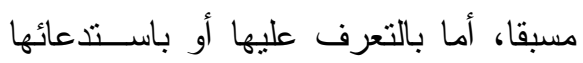
عرض البيانات -- الفيديو المسجل.... الخ، ولئ

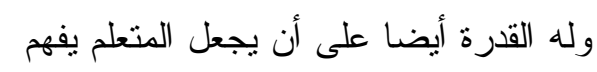
حيث تقوم المعلمة بعمل سيناريو لتقديم مادة

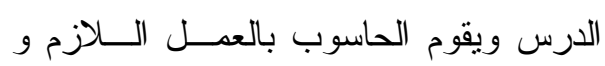

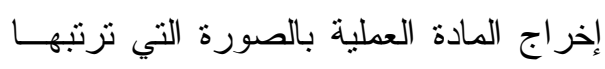
- Internet لقد أصبح الحاسوب وتطبيقاته جزء لا يتجز أ من حياة المجتمعات العصرية. وقد أخذت ثقنية المعلومات المبنية على الحاسوب لهاء تغزو كــل مرفــق مــن مرافـق الحيــاة. فاستطاعت هذه التقنية الحديثة أن تغير أوجه هن فرن

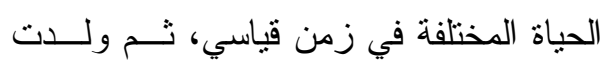

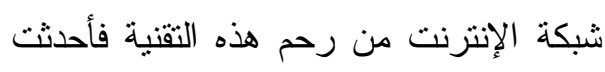

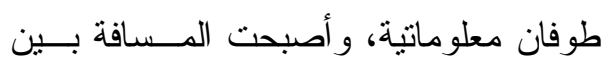
المعلومة والإنسان تقترب من المسافة التـي مئي تفصله عن مفتاح جهاز الحاسوب شيئا فثنيئا،

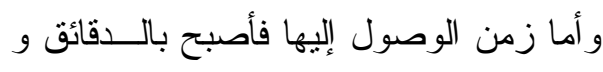

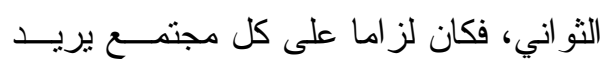

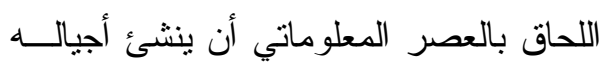
المعلومات، ويدرك معانيها، بحيث يستطيع

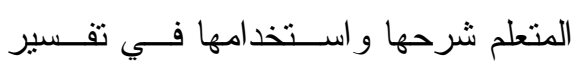
المبادئ و المفاهيم العلمية.

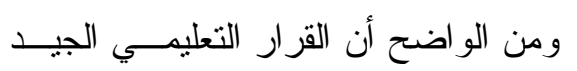

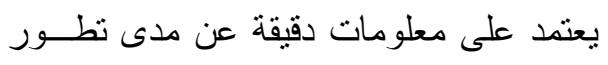
أداء الطالب وتطبيقات إدارة العملية التعليمية

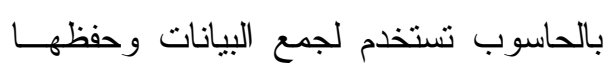
وتعديلها و استرجاعها ومن ثم تقديم التقارير حول المعلومات المتوفرة ويمكن أن تكــــون هذه التطبيقات بسيطة كإعداد دفتر للعلامات، أو تكون أكثر تقدما للتشخيص وتقديم العلاج وذلك حسب احتياجات الطلبة. وقد أثــارت

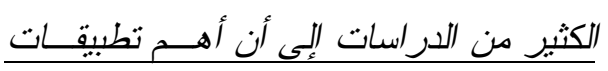

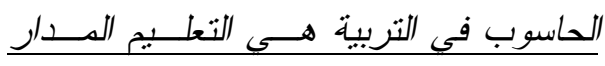

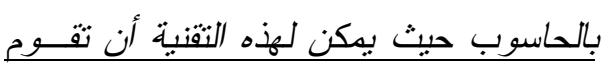

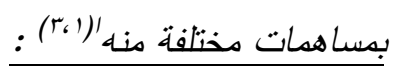

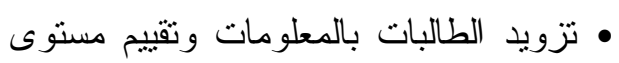
الأداء للطالبة. 
الدر اسية التي تقوم بتدريسها، عــلاوة علــى

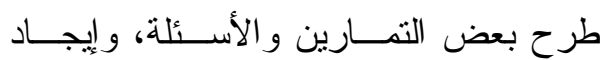

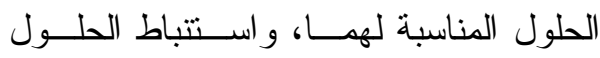

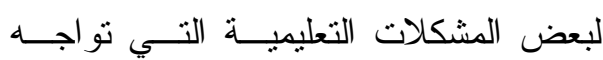

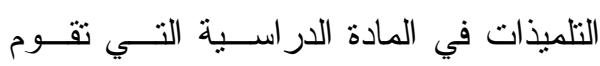
بتدريسها من خلال أحد المواقع الموجــودة على شبكة الانترنت.

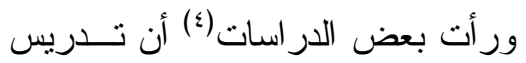

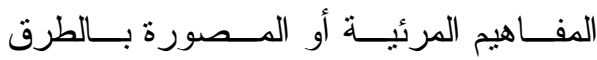

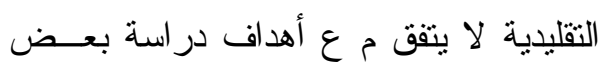

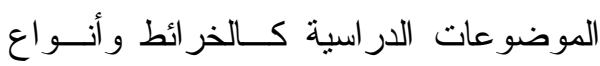

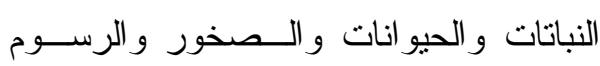

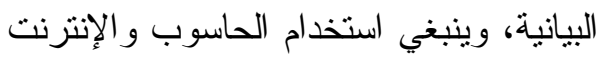

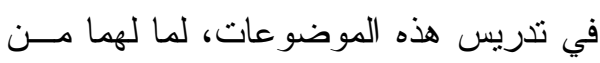

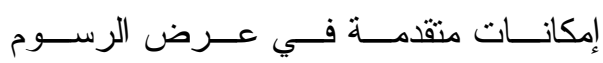
و المجسمات بألو انها الطبيعية و بالبعد الثالث،

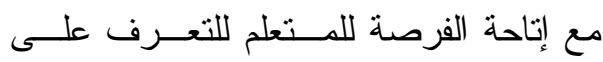
الخو اص المختلفة له، وكأنه يلمسها بيده، كما لئه

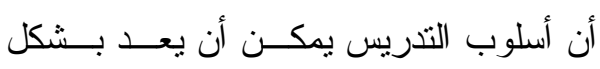

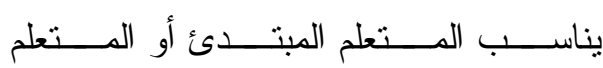
المتخصص. ومن أهم الأسباب الرئيسة التي تجعلنا نستخدم الإنترنت في التعليم هي (').

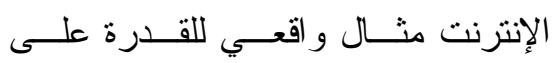

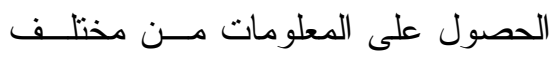

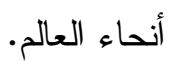

على التعلم من خلال الحاســوب وتثقنياتــه، ويؤهلهم لمحاكمة التغير ات المتلاحقة في هذا العصر، لذا فقد قامت بعض الدول بوضــع

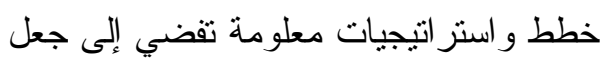
الحاسوب وشبكة الإنترنت عنصر ا أساســيا في البيئة المدرسية. ونرى أن شبكة الانترنت من وسـائل

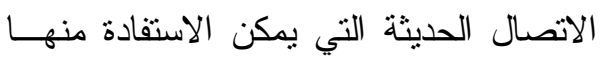

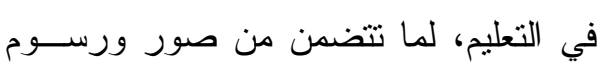

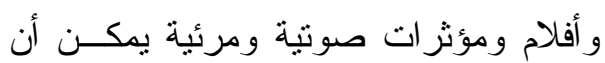

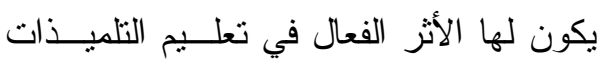
ويعرف الكثير شبكة الإنترنت على أنهــا ل

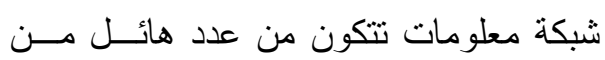

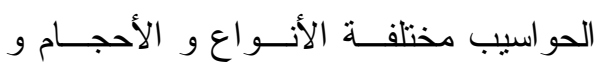

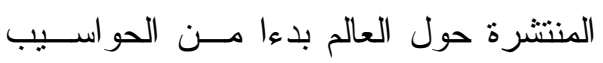
الشخصية و انتهاء بالحو اسب العملاقة". ويتم الربط بينها من خلال برنوكـــول بـول

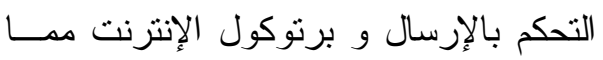

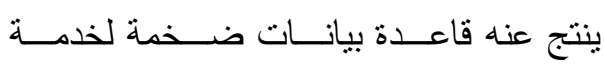
المستخدم كما نجد أن المعلمة التـي تتميـز لتئز بخبرة عالية في مجال التعليم وفــي مجـــال

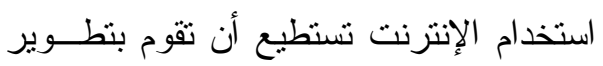
بعض الخطط التعليمية الموجودة على شبكة الانتزنت للوصول إلى الأهــــاف التعليميـــة

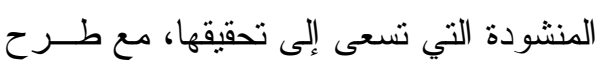

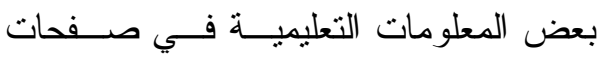

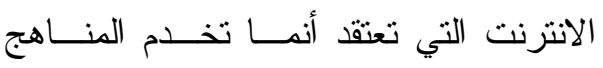


داخل المؤسسة أو الثركة وتـشبه الــشبكة

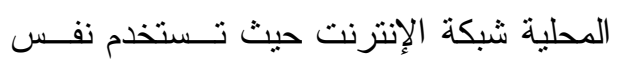

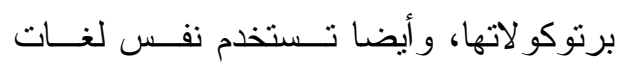

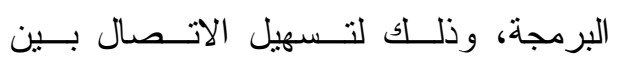
الأثــخاص داخــل المؤســسة أو الــــركة.

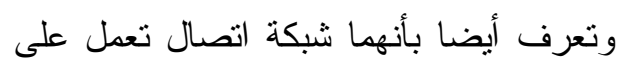
تغطية منطقة محددة جغر افيا مثل (المدرسة،

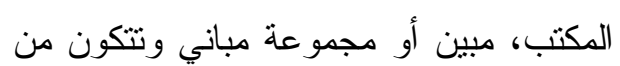
عدد من أجهزة الحاسب موصولة مع جهـاز حاسوب رئيس.(Server). متطلبات الـشبكة

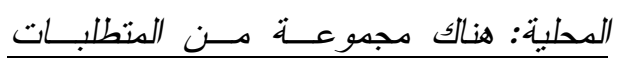

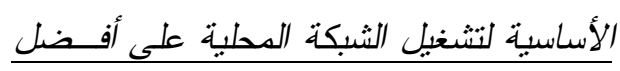
صورة، وهذه المتطلبات هي (1): • الأجزةة: حيث تكون مواصفاتها مناسبة

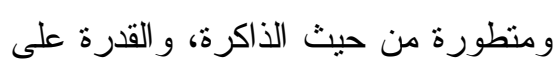

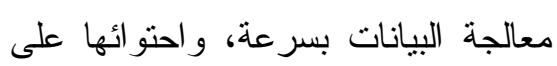

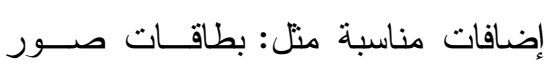
وســماعات صـــوت وبطاقـات فيــديو وشاثات عالية الجودة.

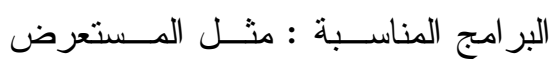

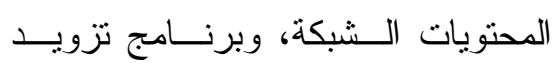

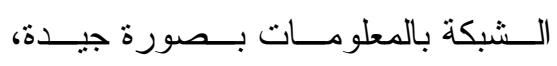
بالإضافة إلى البر امج الخاصة بالإنترنت.

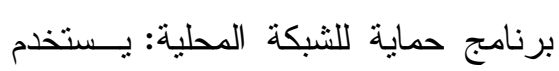

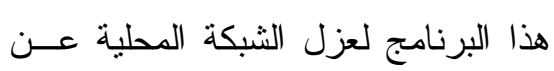

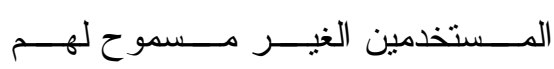

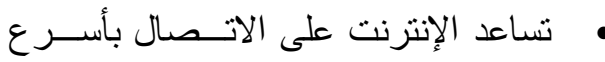
وقت و بأقل تكلفة.

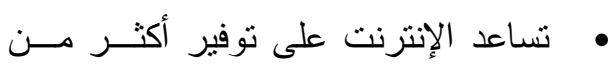
طريقة في التدريس ذلك أن الإنترنت هي تونير الإنترن

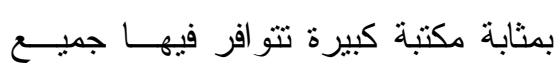
الكتب و البر امج التعليمية. هذا وقد علق ( بيل جيتس) مدير عـام

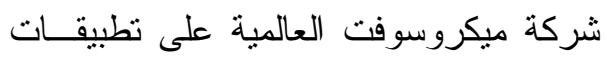

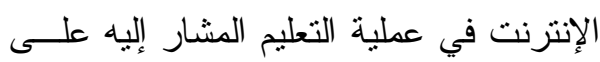

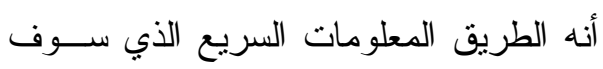
يساعد على رفع المقاييس التعليمية لكل فرد

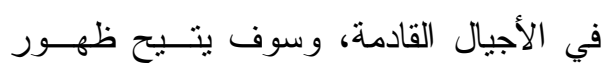
طر ائق جديدة للتدريس و مجالا أوسع بكثير للاختيار • وسوف يمثـلـل التعــــم باســـتخدام

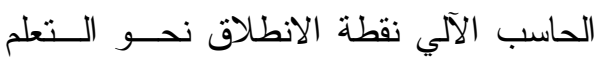

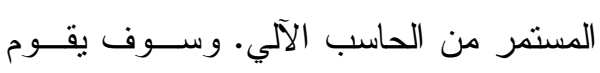
مدرسو المستقبل الجدد بما هو أكتــر مــن فئن

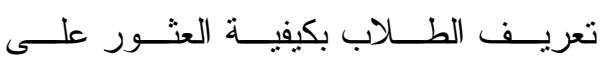

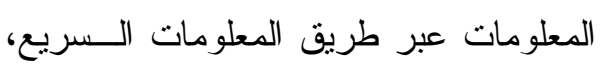
فسوف يظل مطلوبا منهم أن يــدركو ا منتي ليـي يختبرون، ومن يعلقون، أو يثيرون الاهتمام.

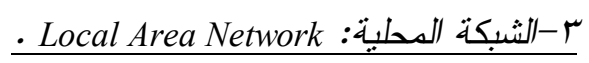

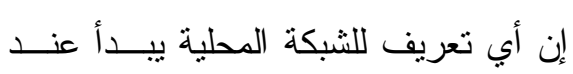

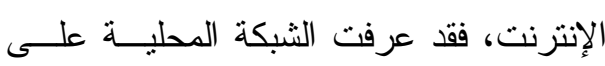

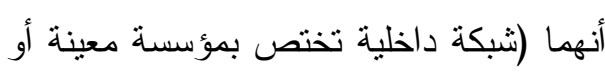

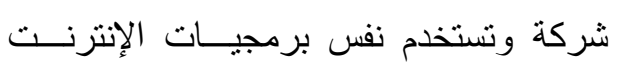

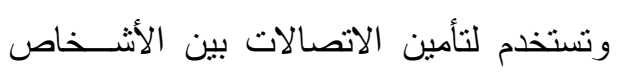


التعليمية الجيدة تسمح للمتعلمين الأفــراد بالتعلم حسب سرعتهم يطــالعون المــادة حسب الحاجة وينقـــمون إلـى الأمسـام بسر عة عندما يستو عبون مفهوما جديد.

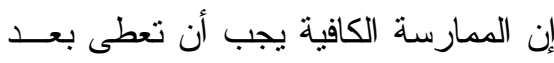

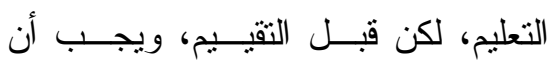
يستجيب البرنامج بشكل ذكي للإجابـات غير الصحيحة، ويتوقع الإجابات الخاطئة

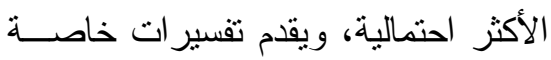
وخبرات تعلم تبعا لتلك الإجابات الخاطئة التي اختارها الطالب، وباختصار تتطلب

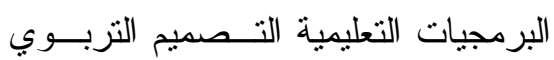

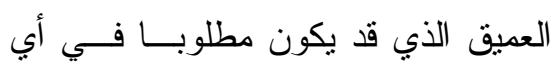
درس جيد يقدم المعلم بالطرق المعتــادة،

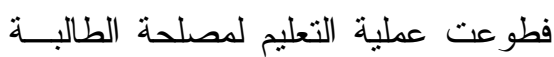
وأعطتها فرصة الــتحكم فــي تعلمهــا،

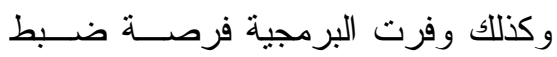

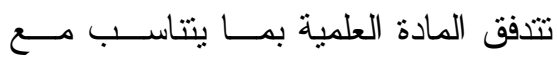

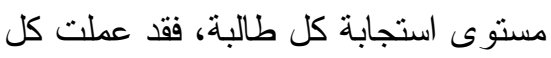

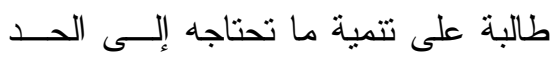

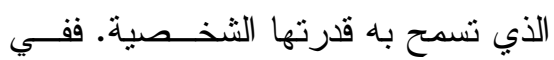
غرفة صف مزدحمة ومشغولة بــالكثير

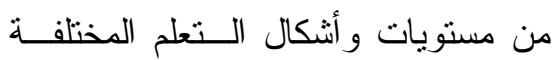
يمكن أن يستخدم المعلمون البرمجيـات

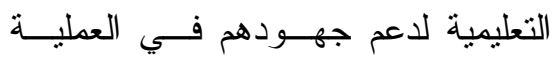
التربوية، وهذه البرمجيات تسنطيع تعليم الطلاب الذين يحتاجون إلى تعليم إضافي
استخدامها، و الاطلاع على المعلومــات الخاصة بالثركة التي تستخدمها. • البرمجة المستخدمة: تـستخدم الـشنبكة

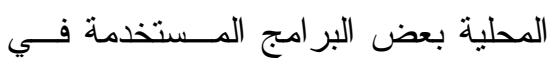

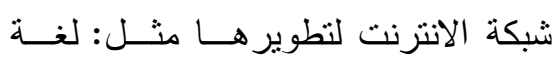
الجافا (Java) التي تسمح بإدخال وسائط متعددة على صفحات الثبكة منل استخدام برنامج (HTML) للقيام ببعض الأعمــال

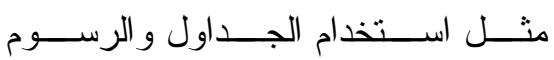
و الارتباطات و أوراق الأنماط المختلفـــة

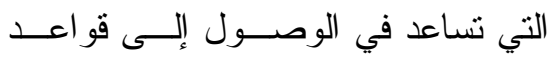
البيانات و المعلومات المطلوبة في الشبكة.

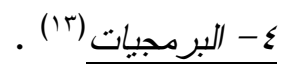

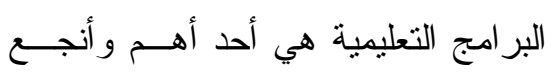

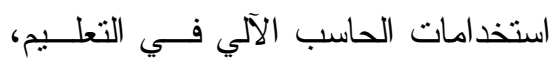

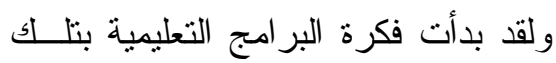

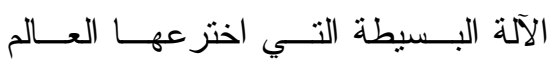
السلوكي (ســكنر B. F. Skinner) فــي منتصف الخمسينات. كانت هــــه الآلـــة

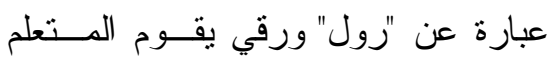

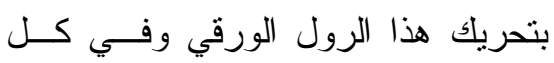

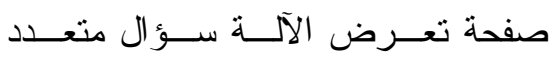

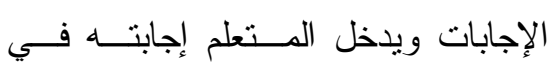
صفحة تالية ومن ثم تتتم عمليــة تعزيــز إجابة المتعلم في صفحة لاحقة. ومنذ ذلك الحين و إلىى اليوم و البر امج التعليمية فـــي

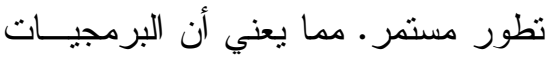


Instruction مساعدا في عملية التعليم منهاب("): التمرين و الممارسة (Drill and Practice) :يهذف هذا النمط إلى تتمية قدرة المتعلم و مهارته في أداء عمل ما بعد دراســته لئه

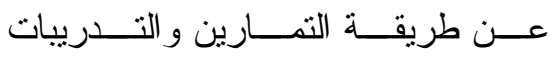
المتكررة. وفي الغالب يسمح البرنــامج

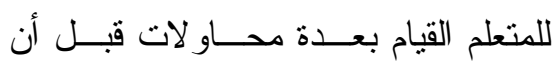
يعطيه الإجابة الصحيحة.

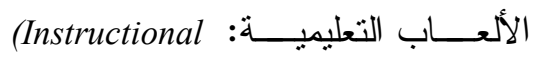
بزئGames) أداء مهارة معينة في سياق لعبة : يمكن

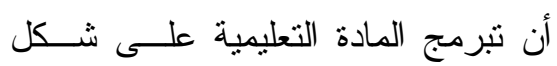
تمارين ولكن في سباق لعبة ؛ من أجـل فيل فئل إيجاد جو يحبب المتعلم ويشوقه للتعلم.

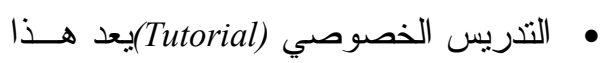
النمط بمثابة معلـــ خــصوصي، حيــث يهدف إلى التفاعل بين الجهاز و المتعلم،

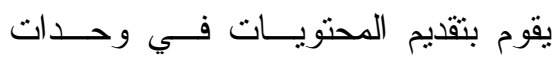

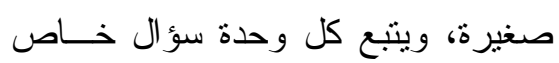

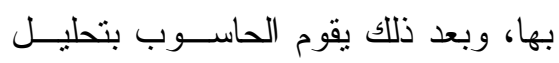

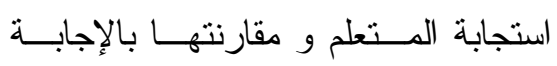
الصحيحة، و على ضوء ذلك تقدم التغذية

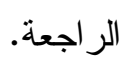
• حل المشكلات (Problem sloving) هنالك نوعان من برامج حل المـشكلات الأول

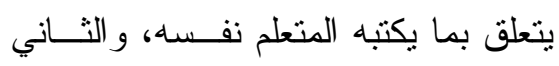

في ضو ء موضوع ما، أو يمكن أن نوفر

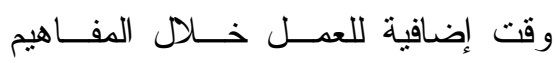

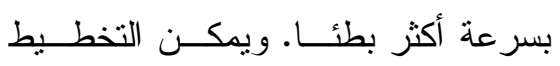
للتعليم بأسلوب العرض الذي يكمل ما هو بون

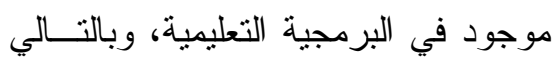
يحصل الطلاب على أسلوب تعلم بــديل

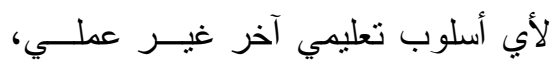

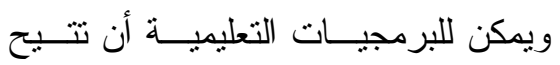
الفرص للطلاب في المدارس الصغيرة أو لأو

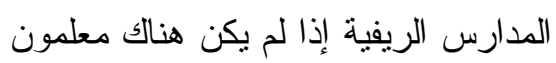

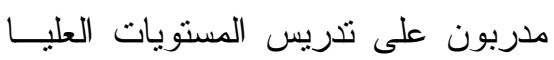
من الرياضيات أو العلوم أو لغات معينة

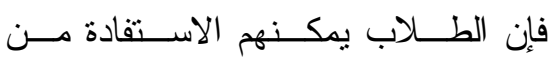
البرمجيات التعليمية في تعلم ما يحتاجون إليه من مواد. أنواع البرمجيات(ب ) :

• برمجيات تعليمية موجهة: وهي برمجيات آنات ذات محتوى مخصص لموضوع معـين

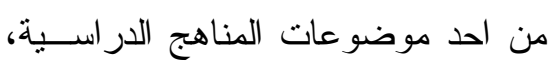
ويصعب تغيير شيء محتو اها.

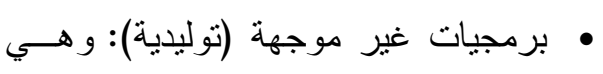

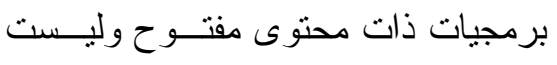

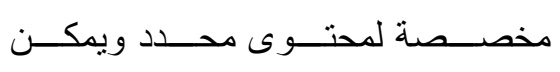
استثمار ها المو اضيع تربوية شتي.

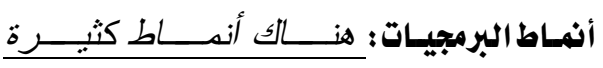
للبرمجيات المستخدمة في التعليم بمساعدة

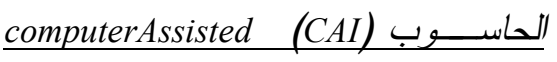


أجز اء جسم الإنسان مثلا، وكذلك التعرف على مواقع الزلازل و البر اكين و أمــاكن حدوثها دون التعرض لخطر ها، أي فـــي ولي و اقع افتر اضي يجسدها أمام المتعلم وكأنه داخل هذه البيئة.

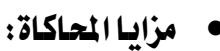

نظر ا لأن البرنامج المستخدم في الدراســـة

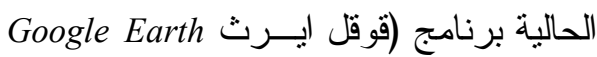
يحاكي الواقع ويجعل المتعلم في بيئة حقيقية و اقعية تذكر الباحثة مزايا المحاكاة التعليميــة و التي من أهمها (0):

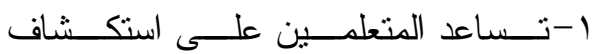

المعلومات بطريقة تفاعلية ديناميكية.

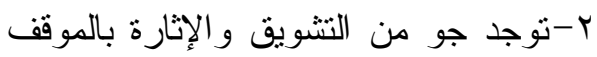

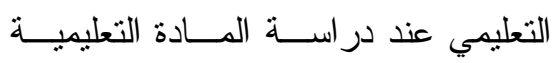

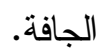

ب-تيــسر للمتعلمــين در اســـة المعلومــات

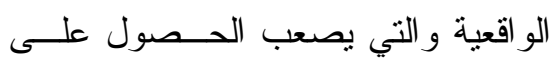
الأصل منها نتيجة البعد الزمني و المكاني لعدوثها.

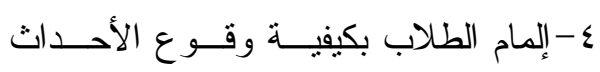
بوضعها تحت الدر اسة و الملاحظة.

ه-تتشيط التفكير الإبداعي لدى المتعلمـين بتقديم الأفكار التعليمية الجديدة.

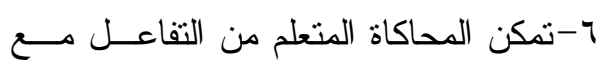
مو اقف تعليمية يصعب عليه التعامل معها

$$
\text { في الو اقع. }
$$

جاهز يساعد المتعلم على حل المشكلات.

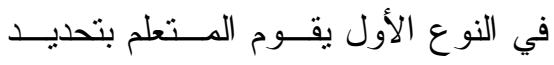

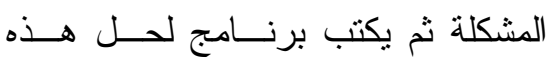
المشكلة من الحاسوب الذي يقوم بإجر اء

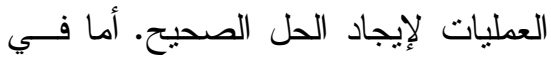
النوع الثاني فيقوم الحاســوب بعمليــات مختلفة تكون وظيفة المتعلم فيها معالجـــة و احدة أو أكثر من التغيرات.

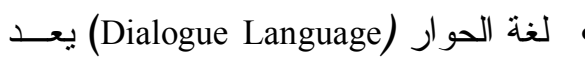
هذا النمط من أحسـدث أنمــاط اســتخدام الحاسوب كوسيلة في التعلم، حيث يحدث تفاعل بين المتعلم و الحاسوب من خـــلال

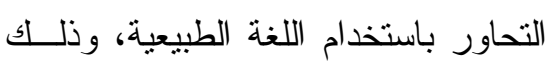
عن طريقة وحدات الإدخال و الإخــر اج، لـابه إلا أنه ماز ال في مرحلة التجربة.

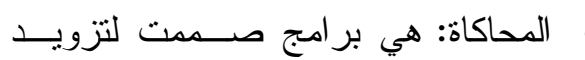

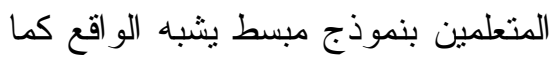

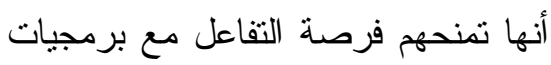

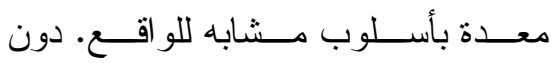

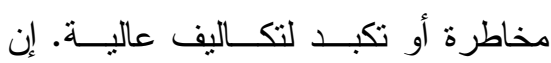

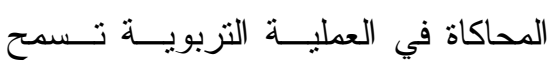

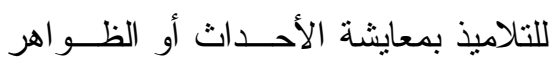

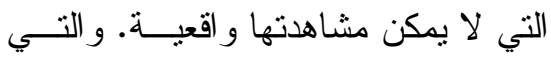
يكون من الصعب أو لخطر تتفيذها فـي ولهي ولئي داخل غرفة الصف. وتستتنج الباحثة أنه

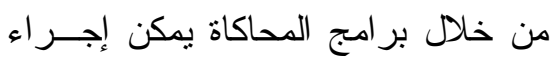

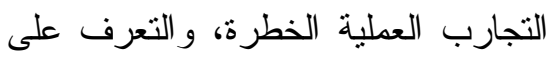


و الصوت، وبيانات الحاسوب، وكــامير ات

$$
\text { التصوير الرقمية و الثابتة وغير ها. }
$$

• تعطي صورة كبيــرة ذات ألــــوان فائقـــة

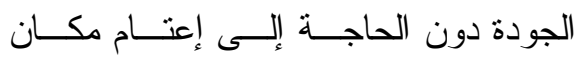
العرض بسبب المعايير البصرية التي يتمتع

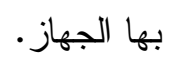

• تمنح المستخدم تحكم أكبر بالمكــان مـنـ

خلال عدسات (الــروم) الخاصــــة القابلـــة

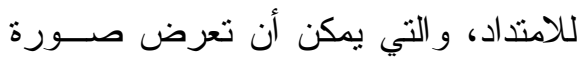

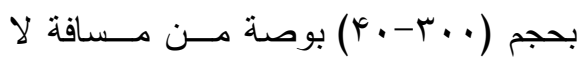

$$
\text { تزيد على المترين. }
$$

• سهوله حمل بعض أنو اع هــذه الأجهـزةة

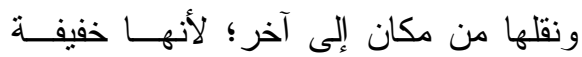

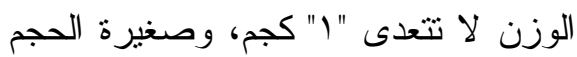
ذات أبعاد محددة.

• ســــولة تــشغيله، و واســتخدامه، ويمكـن الوصول إلى خيار ات الضبط مــن خـلال

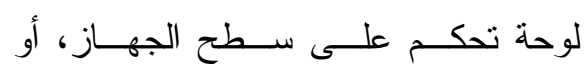
Remote باستخدام جهاز التحكم عن بعـــ .control • يساعد المعلم على عرض مادتــه بـشكل

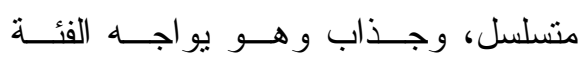

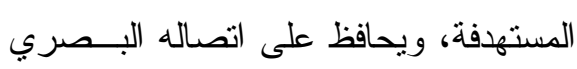

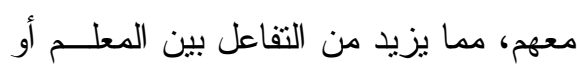

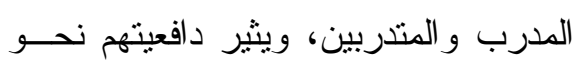

$$
\text { تعلم أفضل. }
$$

0- أجزةة العرض Data Projector

ومن مسمياتها أيضا: أجهزة عــرض المرض

البيانات و الفيــديو Data / Video Projector أجززة عرض الوسائط المتعددة Multimedia (Projector

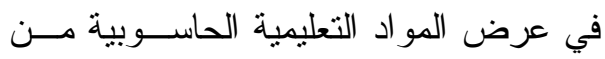
جهاز الحاسوب، كما يمكن اســتخدامها فـي عرض المواد التعليمية المصورة الموجــودة لمهن على شريط الفيديو، أو من جهاز التلفزيون،

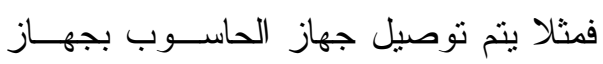

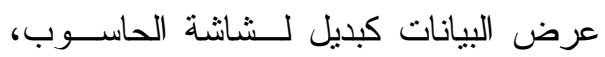
ويتم عــرض البيانــات مــن أي برنـــامج بالحاسوب مكبرة على شانشة عرض خارجية

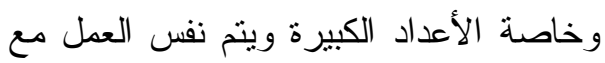
بقية الأجهزة الأخرى، ويستخدم في الفصول الذكية، وفي قاعات الدرس بالجامعات، وفي

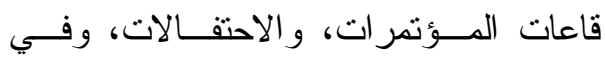
المسار ح و غير ها.

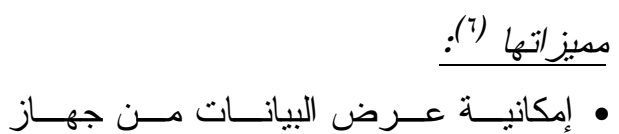
الحاسوب، أو الفيـديو، أو التلفزيـــون، أو الو كامير ا الفيديو، أو جهاز العرض البصري إلى شاثة عرض كبيرة تناعد في معرفة

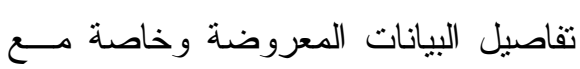
الأعداد الكبيرة. • تقتلاءم مع مجمو عة من مــــاخل الوســائط

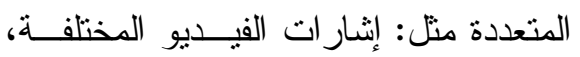


ظهرت أخيرا سبور ات ذكية تظهـر بكــلـ الألوان الطبيعية وتنتخدم بشكل تفاعلي بين

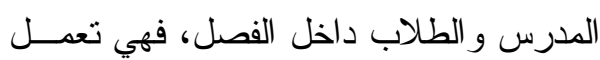

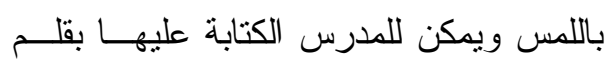
خاص بمجرد تمرير يده عليها، كما يمحو ما بال كتبه إن أر اد بممحاة إلكترونية، وهي مجهزة بهرة

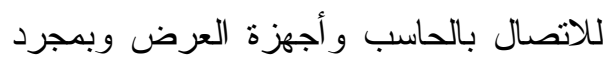
توصيلها تحول في ثوان إلى شاشنة كمبيوتز

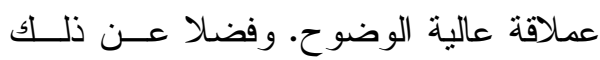
مزودة بسماعات و ميكروفون لنقل الصوت

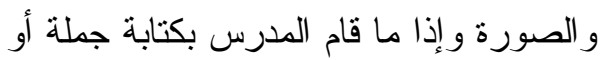

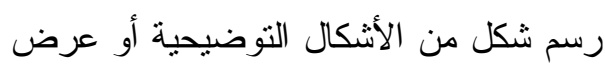

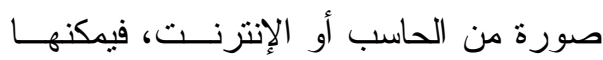

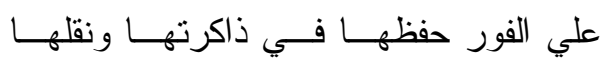
لحاسبات التلاميذ و الطلاب إن أر ادو ا، ويمكن لأي طالب أن يبعث بما لديه من ملاحظــات ومساهمات في الدرس. فهـي مــن أحــدث

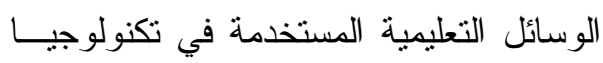
التعليم، و هي نوع خاص مــن اللوحسـات أو السبورات البيضاء الحساسة التفاعلية التـي توعي يتم التعامل معها باللمس : ويتم اســتخدامها لعرض ما على شاشة الكمبيوتز من تطبيقات متتو عة، وتستخدم في الصف الدر اسي، فـي مئي

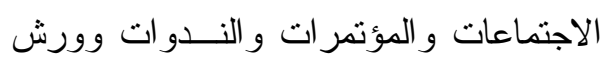

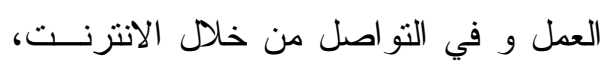

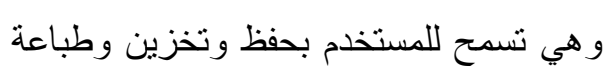

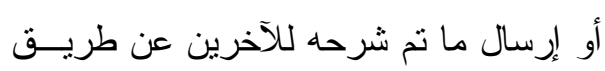

• إنتـــاعة روح التعــاون، و التتــافس بــين

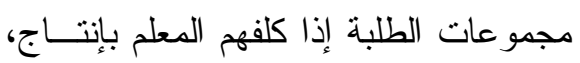
وحوسبة برمجيات تخدم أهداف محددة.

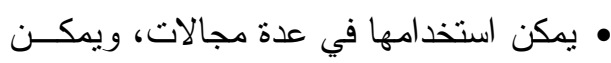

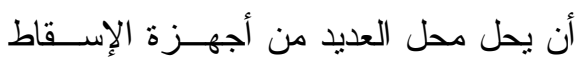
الضوئي • تساعد في التغلب على مشكلة زيادة الأعداد

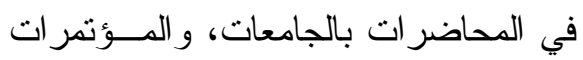

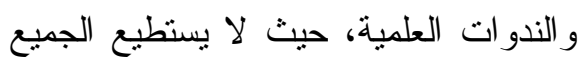

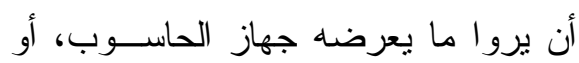
الفيديو . 7-السبورة الذكية Smart Board. هي سبورة يمكن الكتابة عليهــا بـشكل

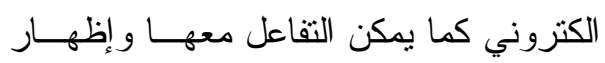

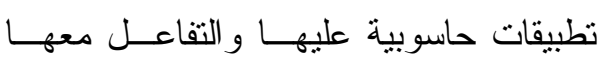
باللمس باليد أو بالقلم أو بـأدوات التأثثــير

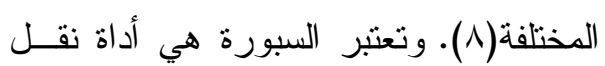
المعلومات من المدرس إلى الطالب على مر

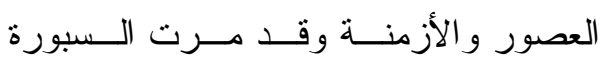

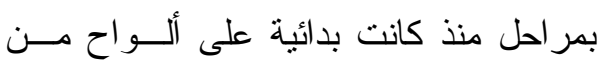

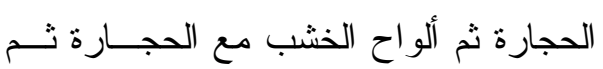
السبورة مع الطباشير ثم الـسبورة البيــضاء

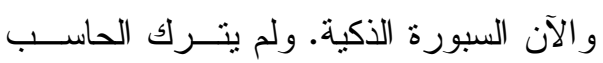

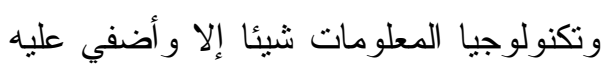
لمسات من التحديث و التغيير فبعد ســنوات

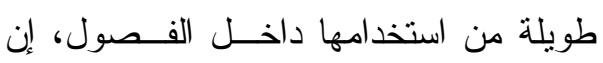

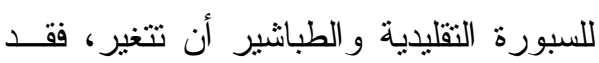


Teaching Station البريد الإكتروني في حالة عدم تمكنهم عـن طاولة عمل للمعلمة

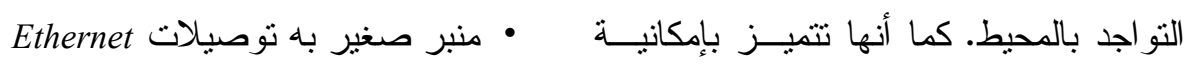

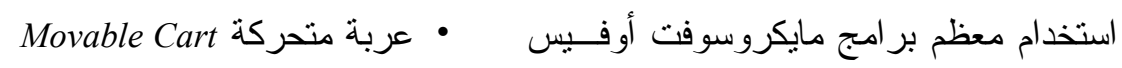

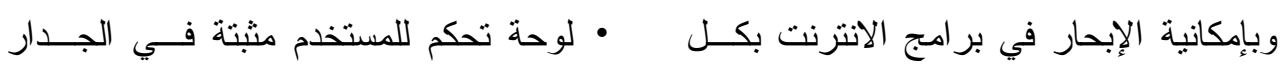

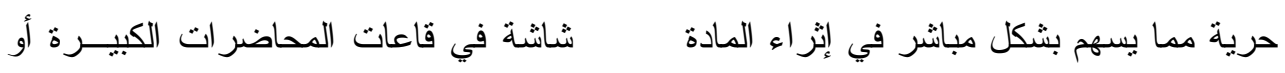

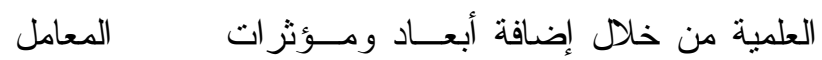

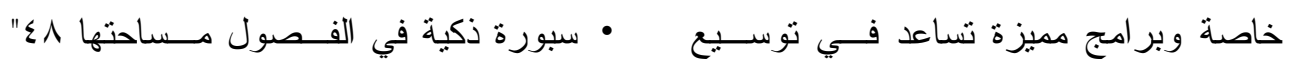

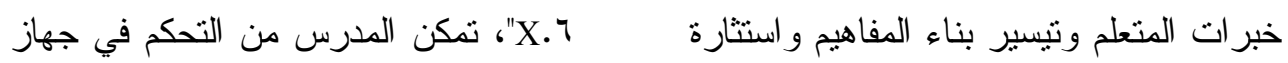

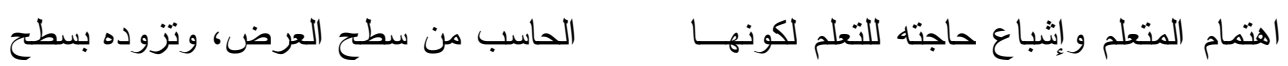

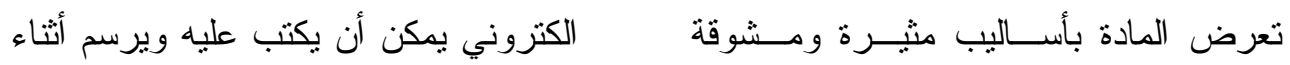

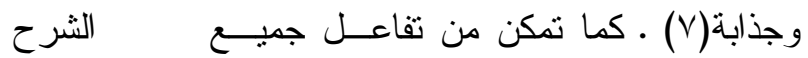

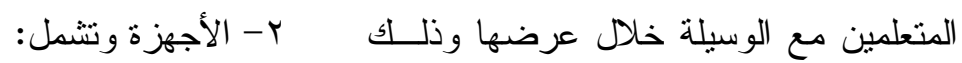

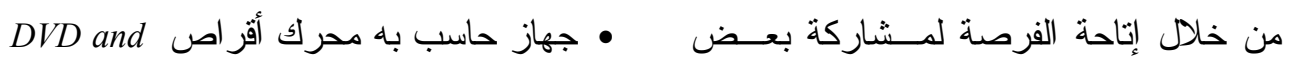

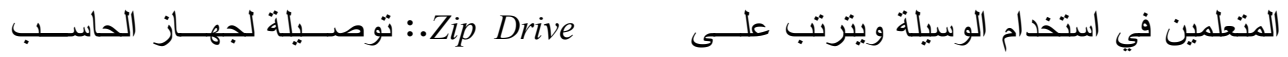

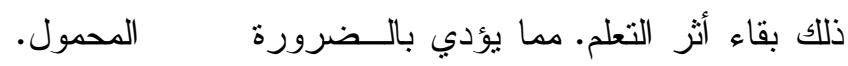

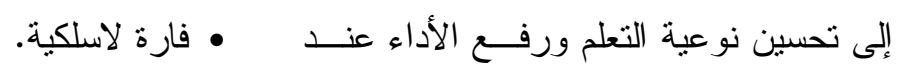

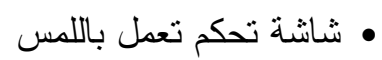
التلاميذ الطلبة أو المتدربين. • جهاز عرض LCD معلق في السقف. تجهيزات الفصول الذكبة والدعم الفني

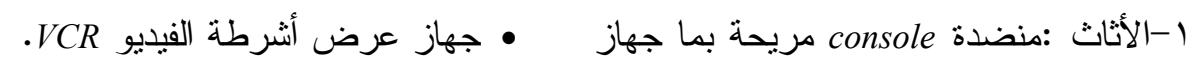
حاسب بــ CD - ROM , DVD , ZIP drive C تليفون.

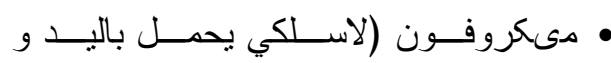
.(lavalier AUX-video Input $\mid$ USB Input •

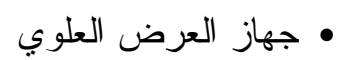
• جهاز لقر اءة الوثائق هocument Reader. • جهاز عرض الثرائح هب ملم. • جهاز عرض أفلام 19 ملم. ومحرك أقراص مرنــة، و انترنـــت عاليــة

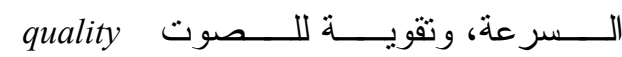
Amplification

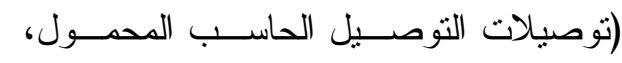

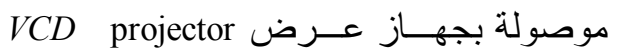
للحصول على صور و اضحة ناصــعة مـــع مفتاح للخز انة. 
أثرطة فيديو • أسس تــصميم الفـصول الذكية * ينبغي أن تكون الفصول الذكية مصممة لتلبية الطلبات المتتوعة للمعلمين

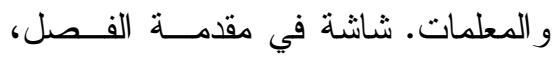
مفاتيح للتحكم في الأنوار الموازية لمقدمة

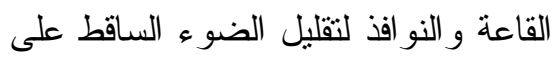
الثنانـة، طاولة قابلة للطي إلــى أســل لتتاسب جهاز عرض الثرائح أو الأفلام مزودة بمقبس كهربائي في متتاول اليــد،

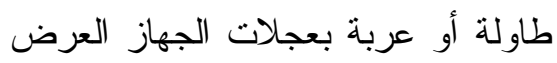

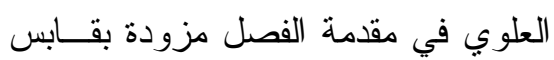
في متتاول اليد، دولاب لتخزين الوسائل

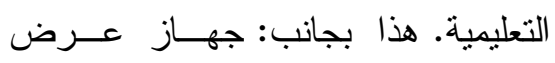
أشرطة الفيديو، جهاز العرض العلوي أو

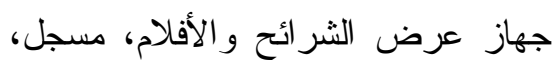
جهاز استقبال تلفزيـــوني فــوق خز انـــة الوسائل أو جهاز عرض فيديو مثبت في لكزي السقف في الفصل الذكي، أنظمة عرض فئر مئر تستطيع استقبال الإشار ات من التلفزيون

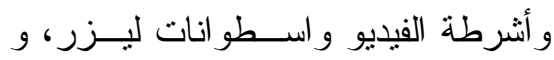
CD - ROM ينبغي تتسيق الإنــارة ونظــام الــصوت وحسات

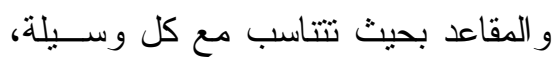
وينبغي دمجها في الفصل علــى أســاس ولس مدروس. • شاشات الحاسب، وهذا يقتضي أن تكون أجهزة الحاسب غائرة ومائلة في الطاولة
• جهاز عرض أو شاثنة RGB.

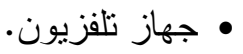
• Cassette Player آلة تسجيل. • أجهزة تشغيل اسطو انات الليزر الهيل Laser disc players

• أجهزة عــرض أثنـرطة الفيــيو players

• أجهزة عرض الكاميرات الفيديو الرقميــة DV Cam player • Video file servers ملفات الصور الصور • إمكانية الاتــصال بــالبر امج التــي تبــث

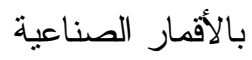
• أجهزة التحكم و تختلف باختلاف الوســائل السمعية البصرية المختارة • لوحة تحكم للمستخدم منثبة في الجدار Stereo Sound •

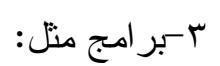
• بر امج الانترنت (Internet Explorer).

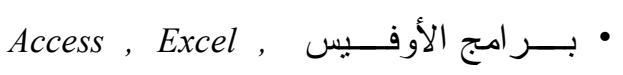
Publisher, Front- PowerPoint, Word page

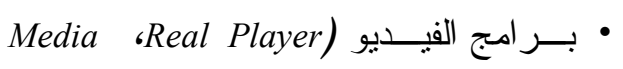
-( Player • برنامج القارئ (7 . • (Reader) • بر امج مكافحة الفيروسات ( virus- anti). ع- ملحقات أخرى نتشل:

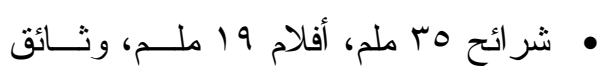
WordPerfect مجسمات ثلاثية الأبعاد، أنثرطة تسجيل، 


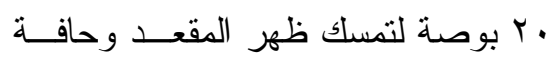
ذر اع طاولة الكتابة. • كما أن فرش قماش سيمنص الأصو ات..

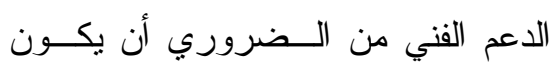
هناك فريق عمل متخصص لديه خبــرة

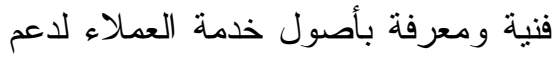

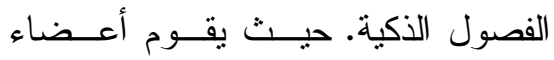

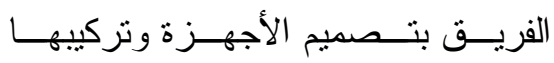

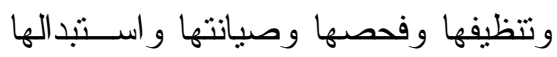

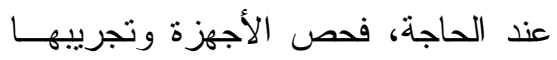

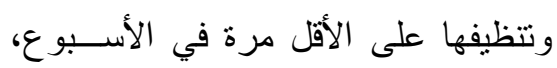

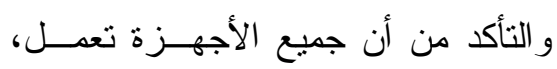
ويتكون العاملون من عدد مــن الفنيـين المتخصصين فـي الوســائل الـسمعية البصرية. تدريب المعلمين على استخدام الفـصول الذكية: يجب تدريب المعلمين و المعلمات على طريقة استخدام الفصول الذكيــة و يمكن أن يقوم الفنيون بتدريب المعلمـين على استخدام الفصول الذكية في بدايــة

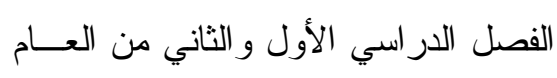
الدراسي. حيث يقومون بتدريب المعلمين

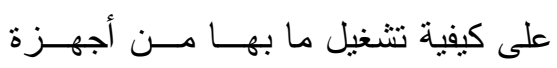

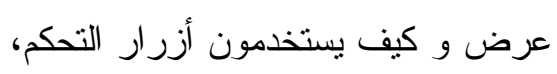

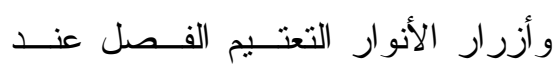

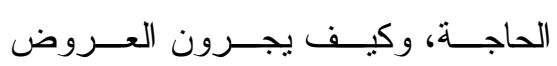
باستخدام جهاز عرض البيانات والصور، ول
وترتفع عن سطح الطاولـــة بمقــدار ع

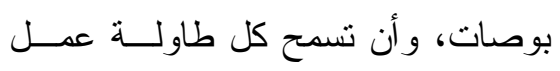

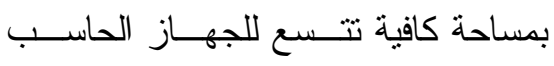

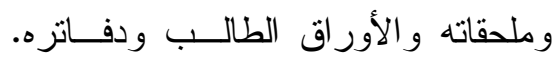

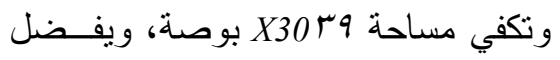
أن تخصص لكل طالب مساحة مقـــدار ها A 1 بوصة، حتى يقوم المعلمون بتقـــيم

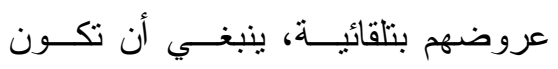

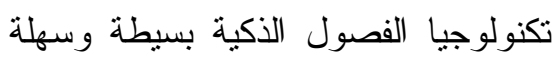
الاستخدام، وأن تكــون مــصدر الهـام للمستخدم الذي بعتمد علــى الارتحـــال و التلقائية ومشاركة الجمهور .

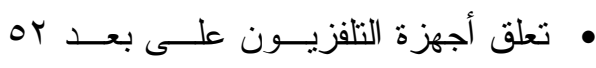
بوصة من الأرض. وينبغـي أن تكــون بـون

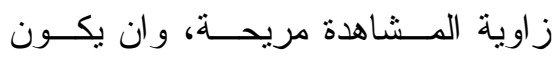
مستوى نظر الطلاب إلى شاشة التلفزيون نفس مستوى رأس المعلم.

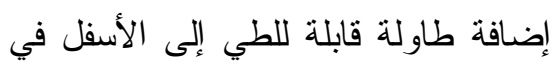

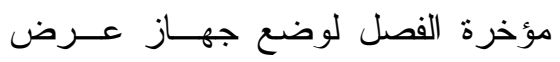

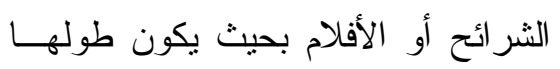

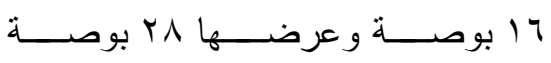

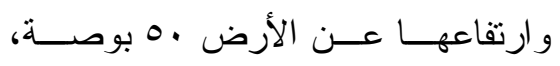

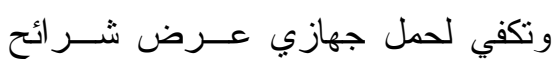
المقارنة الصور • • ينبغي وضع در ابزين خلف الكراسي في ل

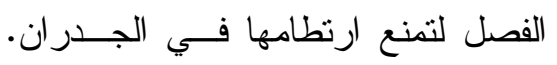
بحيث يكون عرضها 1 بوصة وارتفاعها 


$$
\begin{aligned}
& \text { وطرق إرسال الـصور و الملفـات مـن الإلكتروني (الاستر اتيجيات- الأدوات- } \\
& \text { حاسب المعلم المحمول إلـى حواســيب التطبيقات). القاهرة: عالم الكتب. }
\end{aligned}
$$

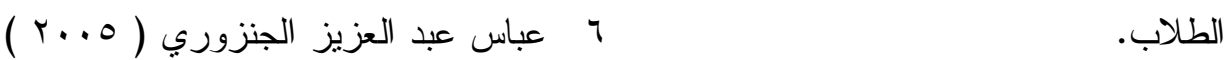

$$
\begin{aligned}
& \text { • فاعلية برنامج وسائط متعددة تفاعلية } \\
& \text { في تحقيق أهداف منهج الحاسب الآلي فئي } \\
& \text { لتلاميذ المرحلة الإعدادية ، ماجستير } \\
& \text { (غير منشورة ) ، كلية النزبية ، جامعة الاعدة كاند }
\end{aligned}
$$

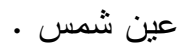

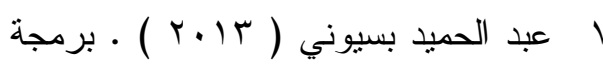

$$
\begin{aligned}
& \text { الانترنت ، القاهرة ، الدار العالمية للنشر }
\end{aligned}
$$

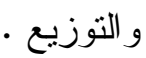

$$
\begin{aligned}
& \text { ^ عبد العزيز طلبة عبد الحميد (•(ب). } \\
& \text { سلسلة استراتيجيات التعلم الإكتروني. }
\end{aligned}
$$

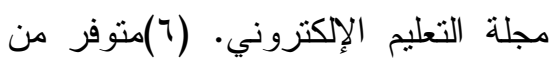

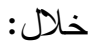

$$
\begin{aligned}
& \text { http://emag.mans.edu.eg/index.php?pa } \\
& \text {.ge }=\text { news\&task }=\text { show\&id } 102
\end{aligned}
$$

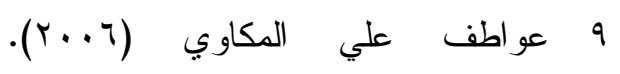

$$
\begin{aligned}
& \text { أساسيات البرفتوحة }
\end{aligned}
$$

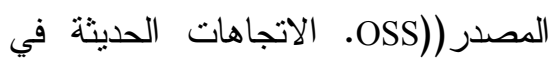

$$
\begin{aligned}
& \text { المكتبات و المعلومات، المجلد بال، العدد الجد }
\end{aligned}
$$

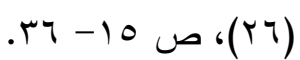

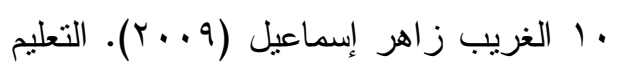

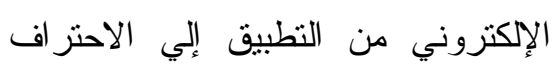

$$
\begin{aligned}
& \text { و الجودة. القاهرة: عالم الكتب. }
\end{aligned}
$$

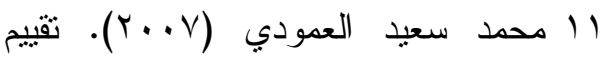

$$
\begin{aligned}
& \text { واقع تدريب الحاسب في كلية التزبية }
\end{aligned}
$$

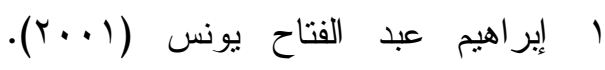

$$
\begin{aligned}
& \text { تكنولوجيا التعليم بين الفكر و والواقع. }
\end{aligned}
$$

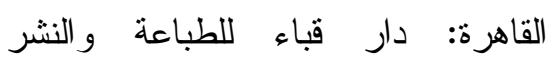

$$
\begin{aligned}
& \text { و التوزيع. }
\end{aligned}
$$

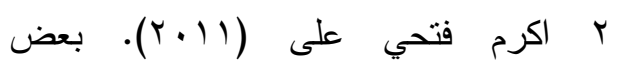

$$
\begin{aligned}
& \text { متغيرات تصميم وجهات التفاعل } \\
& \text { و استر اتيجيات التعلم المتكاملة في مقرر }
\end{aligned}
$$

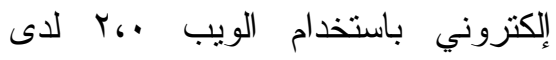

$$
\begin{aligned}
& \text { الطلاب المتعلمين بكلية التربية النوعية. }
\end{aligned}
$$

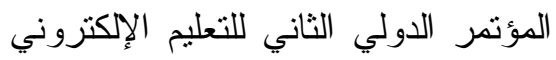

$$
\begin{aligned}
& \text { و التعلم عن بعد. الرياض. }
\end{aligned}
$$

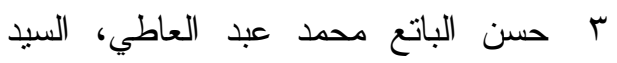

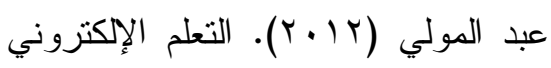

$$
\begin{aligned}
& \text { الرقمي (النظرية- التصميم- الإنتاج). } \\
& \text { الإسكندرية: دار الجامعة الجديدة للنشر • النمئ } \\
& \text { ع ريما سعد الجرف (1) (ب). منطلبات } \\
& \text { الانتقال من التعليم التقليدي الي التعليم } \\
& \text { الالكتروني. دراسات وبحوث المؤتمر } \\
& \text { العلمي الثالث عشر للجمعية المصرية } \\
& \text { للمناهج وطرق التدريس. جامعة عين } \\
& \text { شمس. القاهرة. } \\
& \text { 0 ريهام الغول، أمين صلاح الدين } \\
& \text { (10 (10). تكنولوجيا التعليم و التنريب }
\end{aligned}
$$




$$
\begin{aligned}
& \text { 11 وليد سالم محمد الحلفاوي (11) (Y). } \\
& \text { التعليم الإكتروني "تطبيقات مستحدثة". } \\
& \text { القاهرة: دار الفكر العربي. }
\end{aligned}
$$

19. Barker, J., \& Gossman, P. (2013). The learning impact of a virtual learning environment: students' views. Teacher Advancement Network Journal, 5(2.(

20. Caplow, Julie (2006). "Where do I put my course materials?", Quarterly Review of Distance Education, Vol.7, No.2.

21. Hylen, J. (2007). Open educational Resources: Opportunities and Challenges e-School News online, No 5, PP 1-4.2

22. Istenic Starčič, A., Cotic, M., Solomonides, I., \& Volk, M. (2016). Engaging preservice primary and preprimary school teachers in digital storytelling for the teaching and learning of mathematics. British Journal of Educationa 20. Technology, 47(1), 29-50

23. Mascarell, M. D. M., \& Cabedo, J. L. G. (2014). Entorno virtual de aprendizaje y resultados académicos: evidencia empírica para la enseñanza de la Contabilidad de Gestión. Revista de Contabilidad, 17(2), 108-115.

24. Penttilä, J., Kallunki, V., Niemi, H. M., \& Multisilta, J. (2016). A Structured Inquiry into a Digital Story: Students Report the Making of a Superball. International Journal of Mobile and Blended Learning (IJMBL), 8(3), 1934.

25. Rahimi, M., \& Yadollahi, S. (2017). Effects of offline vs. online digital storytelling on the development of EFL learners' literacy skills. Cogent Education, 4(1), 1285531.

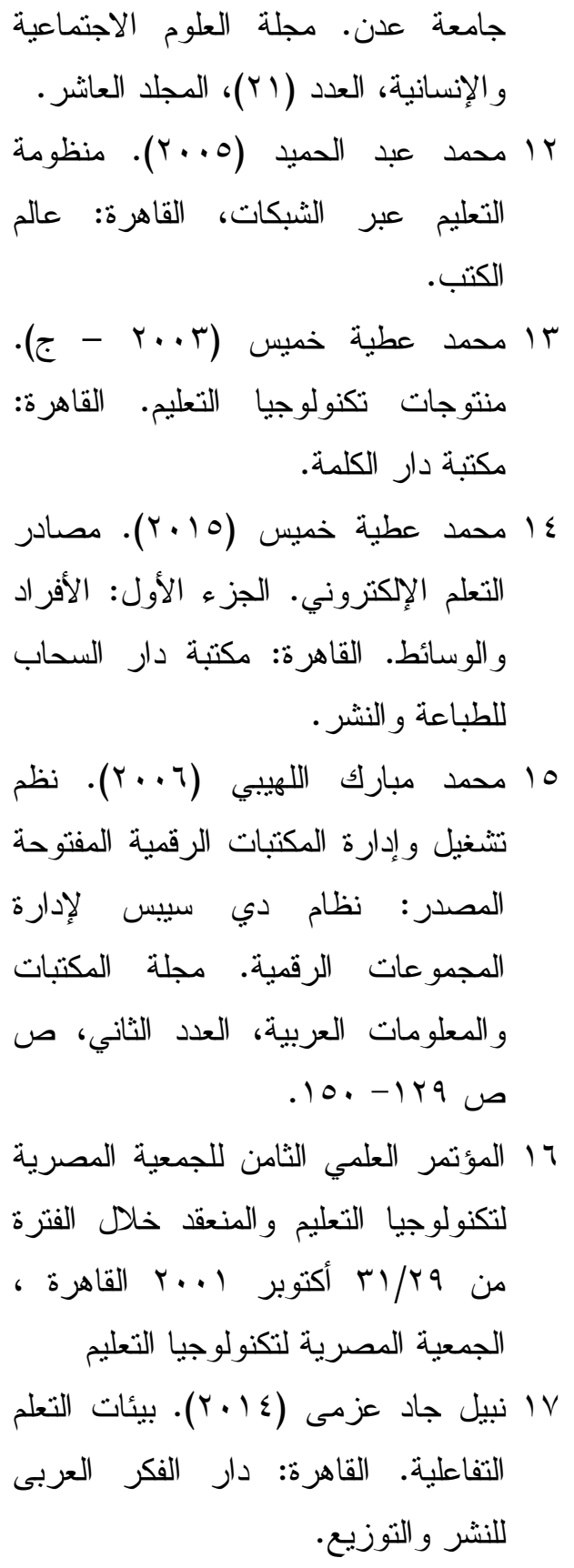


(20)

27.Yueqing, Y.\& Lei, F. (2011). Trends of Open Educational Resources in Higher education, Hong Kong.Springer Berlin Hieldberg, PP146-156
26. Swan, $K$ (2004). Relationships Between Interactions and Learning in Online Environments, Sloan-C Editor for Effective Practices in Learning Effectiveness. 